\title{
12
}

\section{Moving Towers: Worlding the Spectacle of Masculinities Between South Pentecost and Munich}

\author{
Margaret Jolly
}

\section{A small gol in Germany}

On 10 June 2009, outside the austere stone façade of the State Museum of Ethnology in Munich, an unusual construction began to emerge: a latticed wooden tower, tethered with vines, and tapering to the top. Commissioned by anthropologist and filmmaker Thorolf Lipp, this was a quarter-size replica of a land-diving tower, or gol. ${ }^{1}$ It was fashioned by three men, Betu Watas, Tolak Telkon and Mathias Wataskon, who had been flown from South Pentecost, Vanuatu, to build it for the opening of an exhibition of Lipp's photographs, entitled UrSprung in der Südsee: An Encounter with the Pentecost Landivers. ${ }^{2}$ They had already spent some weeks in Obergünzburg, a small town in Bavaria, where they had reassembled an im, a bamboo and thatch house, replete with bamboo beds and kitchen artefacts, shipped from Vanuatu to complement the South Seas collection in a local museum. 


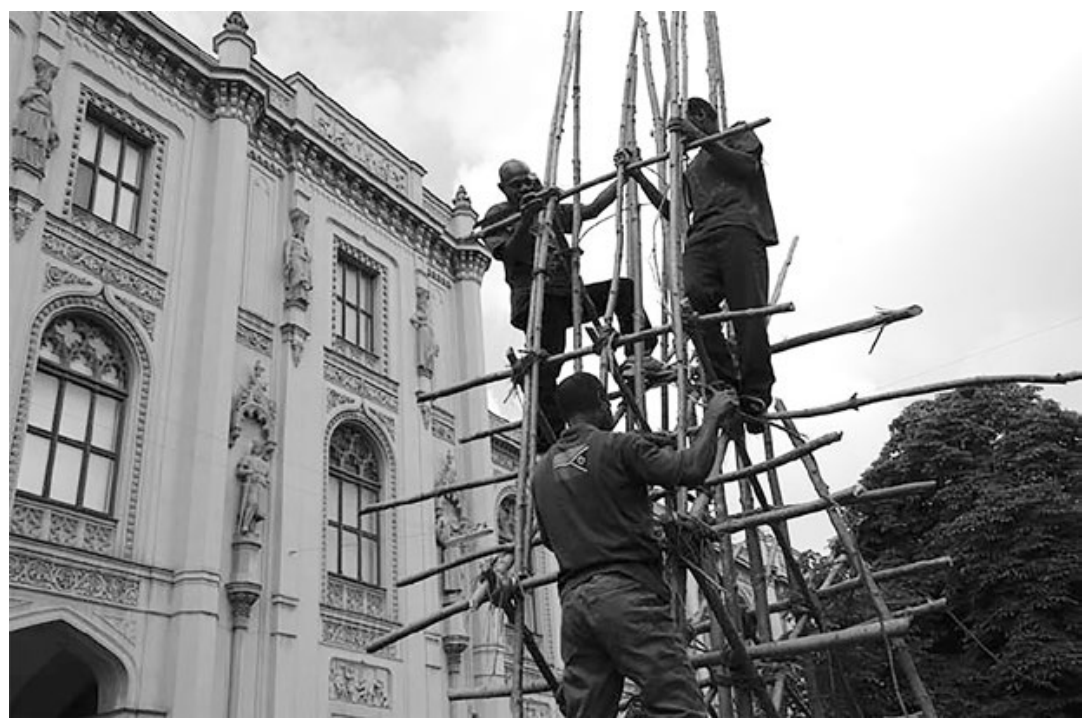

Figure 58. Betu Watas, Tolak Telkon, and Mathias Watskon building the one-quarter-size model of a land-diving tower in front of the State Museum for Ethnography in Munich, June 2009.

Source. Photographed by Jacob Kapere and used with permission.

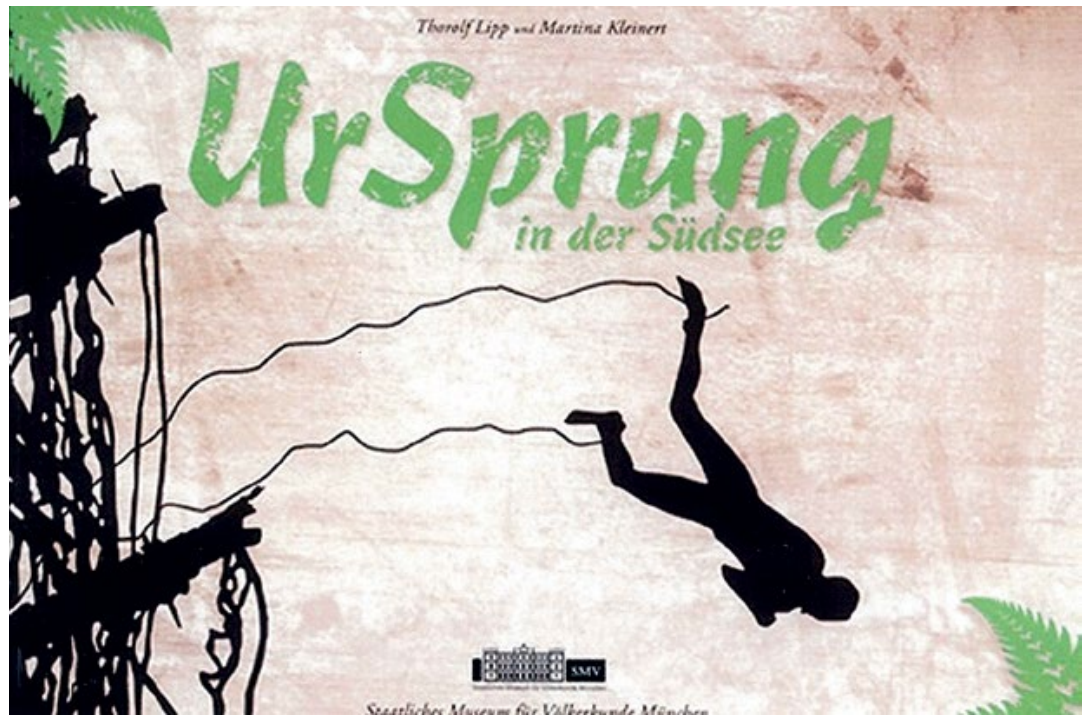

Figure 59. UrSprung brochure.

Source. Brochure in author's library. 
I met the three men there, and talking in Bislama and a smattering of $\mathrm{Sa}^{3}$ (the tok ples that I learnt during several sojourns in South Pentecost from 1970), heard that they had relished the deep green Bavarian landscape, the pristine streams and the local rural hospitality with its abundance of German bread and beer. On 4 June, they had also attended the closing of an exhibition of Pentecost Island jubwan masks from Lipp's collection, at Iwalewa-Haus in Bayreuth. We then moved on to Munich where, while the tower was being constructed, Thorolf had arranged for the men to camp in a small caravan at the back of the museum. Every night kava sessions preceded takeaway meals from pizza bars and Asian restaurants. On their days off from building the tower, we toured the city thronged with holiday crowds, climbed up bell towers and on Sunday joined the packed congregation in the opulent central Catholic cathedral. These three men were not world travellers; only one of them had left Vanuatu before, as a seasonal worker to New Zealand. They spoke neither German nor English, only Bislama and Sa. Though looked after well by Lipp and his partner Martina Kleinert, and accompanied and supported on their travels by Jif Jacob Kapere, Head of the Film Unit at the Vanuatu Cultural Centre (VKS), they were sometimes visibly apprehensive. This was not just because they were inexperienced travellers, but because of events back in South Pentecost in the months before their departure. Some of the details were divulged and fleshed out over lunch one day in a beer hall.

3 Bislama is the lingua franca of Vanuatu, a variant of Melanesian Pidgin. Sa is the language spoken in South Pentecost by approximately 2,700 speakers today. According to Murray Garde, it has five distinct dialects, thus manifesting great internal diversity. It is the subject of ongoing research by Murray Garde, Nicholas Evans and another scholar under an ARC Laureate Fellowship awarded to Nicholas Evans, 'Wellsprings of Linguistic Diversity', which commenced in July 2014. 


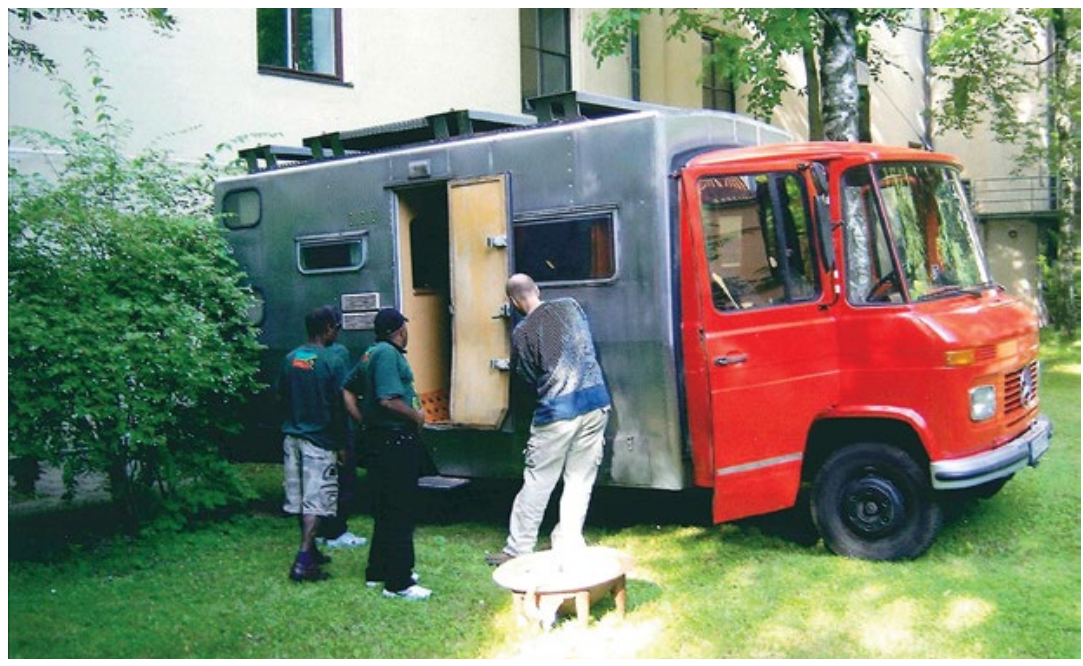

Figure 60. The caravan behind the museum in Munich.

Photographed by Lamont Lindstrom, 9 June 2009.

Thorolf Lipp's main interlocutor and confidante in Bunlap village, Bebe Malegel, a middle-aged, healthy man, had died suddenly in March 2009. Some thought he was killed by sorcery; some suggested this was at the behest of his uncle, Jif Telkon Watas. ${ }^{4}$ (Others later told us that Bebe had exceeded his authority and had been killed by an armwat ensanga, a malevolent ancestral spirit, angered by Bebe's plan to export both the $i m$ and the gol. $)^{5}$ The descriptions of his death and burial offered by the trio of men in Munich were circumspect if gruesome. They said Bebe Malegel was buried very quickly after his death and, oddly, that blood was seeping through the pandanus textiles (baji) in which his body was wrapped, suggestive of foul play or sorcery.

$4 \quad$ Jif Telkon Watas is also known by his last title, Liusbangbang.

5 This was the dominant explanation I was offered during a visit to Bunlap in April 2013, admittedly by close kin of Jif Telkon Watas. Still some of them were critical of his long residence away from Pentecost, in Erakor near the capital Port Vila, and his presumption of a monopoly on custodianship and brokerage of the gol. Lipp refrains from repeating such allegations, stating only apropos the death of Bebe Malegel, his dear friend and Jif Telkon's opponent, that 'all circumstances indicate that it did not have a natural cause'. See Guido Carlo Pigliasco and Thorolf Lipp, 2011, 'The islands have memory: Reflections on two collaborative projects in contemporary Oceania', The Contemporary Pacific 23(2): 371-410, p. 397. As this chapter goes to press I have just become aware of a recent book edited by Martina Kleinert and Thorolf Lipp in German, entitled Auf Augenhöhe? Von Begegnungen mit der Südsee und angewandter Ethnologie but have not been able to consider this here. 
12. MOVING TOWERS

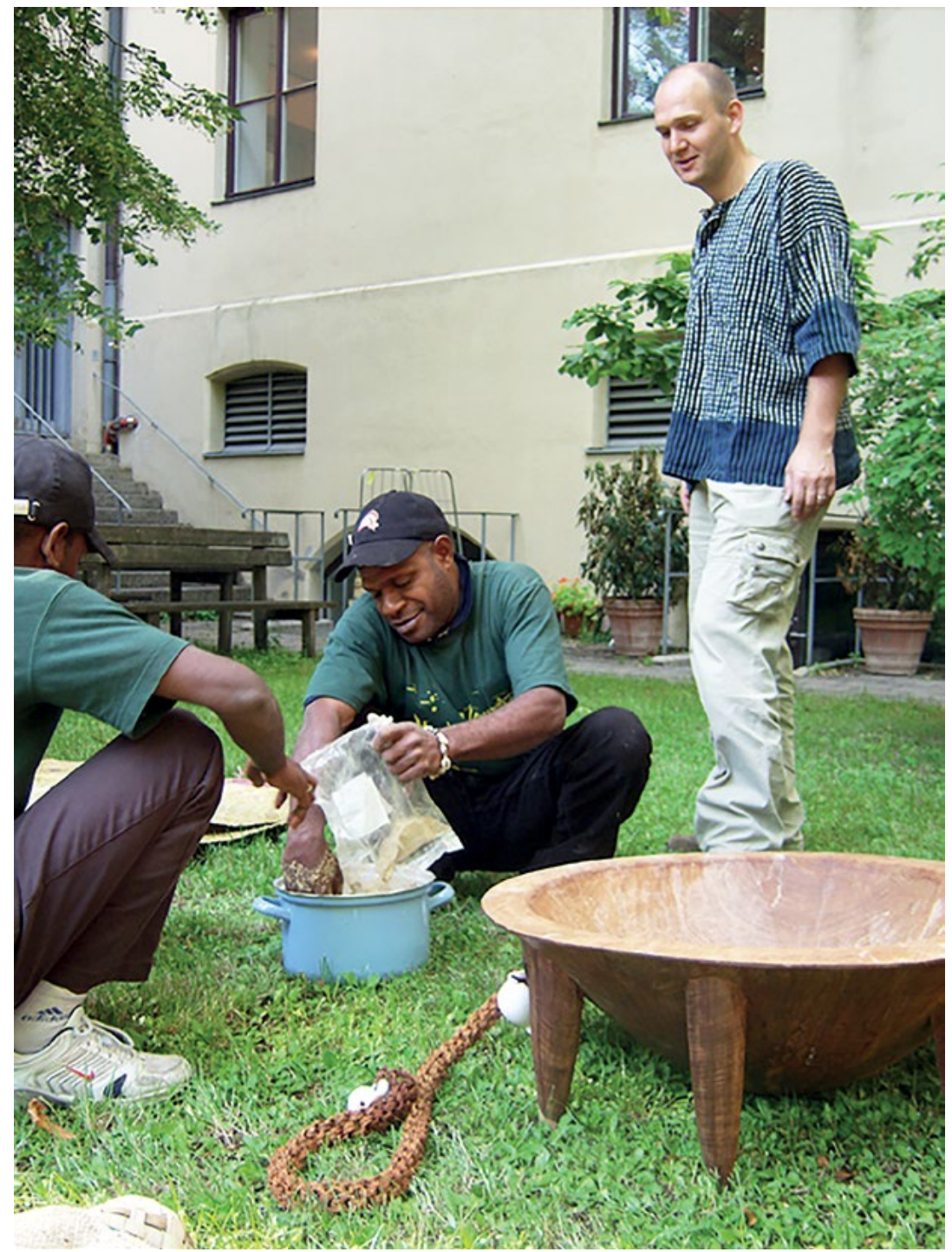

Figure 61. Kava preparation.

Photographed by Lamont Lindstrom, 9 June 2009. 


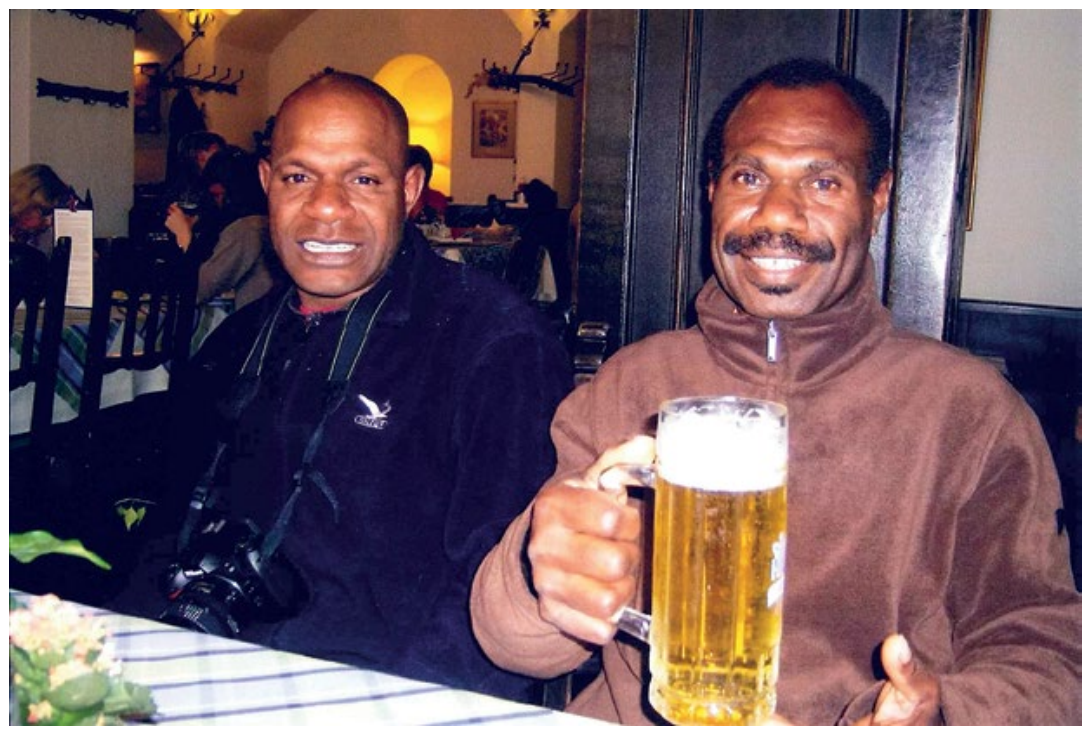

Figure 62. Lunch at the beer hall.

Photographed by Lamont Lindstrom, 9 June 2009.

Bebe Malegel, together with several other high-ranking men in Bunlap, had agreed to collaborate with Lipp to build a gol in Munich to celebrate this iconic spectacle of kastom from Pentecost and Vanuatu, and to help promote exhibitions of Lipp's films and photographs and his collection of jubwan masks. This plan to build a small tower in Munich had been violently opposed by Jif Telkon Watas, in Lipp's words, 'still the most influential and feared man of Bunlap', ${ }^{6}$ even though he had been living since 1995 in the peri-urban village of Erakor Haf Road on the outskirts of Port Vila. When the men originally scheduled for the trip to Munich arrived in Port Vila in January 2009 to secure passports and visas, Telkon informed the police, the Vanuatu Cultural Centre and the Malvatumauri (the National Council of Chiefs) to try to prevent them departing. He made angry comments to the press and on television that alleged both theft of national heritage, and of his own cultural property, since he claimed control of the kastom of the gol and did not approve of this model tower being built overseas. Lipp suggests a majority of men at a village meeting in Bunlap decided

$6 \quad$ Pigliasco and Lipp, 'The islands have memory', p. 393. 
the Munich project should proceed, ${ }^{7}$ but, cowed by Telkon's violent public opposition and perhaps fearing that they may suffer the same fate as Bebe Malegel, several high-ranking men who were due to depart for Germany withdrew.

And so alternative arrangements proceeded in secret; the three men who did dare venture to Munich were from South Pentecost but then resident in Port Vila, and were rather younger, and not influential kastom leaders. After consultations with Ralph Regenvanu, then Director of the Vanuatu Cultural Council, and with Jacob Kapere of the Vanuatu Cultural Centre (VKS) Film Unit, Lipp decided to risk continuing with the German visit. Arrangements were well advanced, Lipp had the support of the VKS and the Malvatumauri and it seemed mutually advantageous to confront Telkon's threats and erode his monopolistic control over the export of the gol. This was despite many cautions from critics in Germany: that Lipp was promoting a 'cultural zoo', exploiting an exotic, eroticised spectacle $^{8}$ and that his aims of 'reverse anthropology' and reciprocal empowerment were vitiated by unequal relations with illiterate, unworldly men. Some even suggested that the punning title of the exhibition UrSprung (origin, jump into life) resonated with dubious German notions of a 'mythic consciousness'. ${ }^{9}$ Many warned that continuing with the project risked further conflict, even death. But he decided after much soul-searching to continue: 'This was not the moment to stop, it was the moment to continue', ${ }^{10}$ in order to break what he saw as Telkon's presumptuous chiefly authority, a desire he also imputes to those three men who dared to go to Munich, who were, he suggests, 'outraged by what had happened in Bunlap'. ${ }^{11}$ After some personal anguish about the ethics and the politics of this tragic situation, Lamont Lindstrom and I, who were both attached to CREDO ${ }^{12}$ in Marseille at the time, decided to join the group to offer sympathy and moral support, and to witness the worlding of this spectacular masculine performance.

\footnotetext{
7 Ibid., p. 397; email from Thorolf Lipp to author, 22 May 2009.

8 Pigliasco and Lipp, 'The islands have memory', p. 386.

9 Ibid., p. 385.

10 Ibid., p. 398.

11 Ibid.

12 This is the acronym for Centre de Recherche et Documentation sur l'Océanie based at the Université de Provence and funded by both Centre National de le Recherche Scientifique (CNRS) and L'ecole des Hautes Etudes en Sciences Sociales (EHESS).
} 
There was an extraordinary paradox at the heart of this bitter conflict since Jif Telkon Watas himself had already been involved in exporting the gol, not as a small replica but in full scale, complete with divers, to places overseas (to Australia and to Japan) and to other islands in the archipelago. He had arranged for many men and women to travel to the island of Espiritu Santo and to construct a model village and gol tower during the making of the execrable B-grade movie Till There Was You in 1990. ${ }^{13}$ Many people from Bunlap village were employed to act as extras, but since the producers did not pay extra money for the right to photograph the land dive, the tower was torn down on Telkon's instructions. The Pentecost Island Council of Chiefs had vigorously opposed this relocation of the gol. Later, in 1995, Jif Luke Fargo from Londot village (near Wali) on the west coast of Pentecost built a tower in Santo but was opposed by the Kaonsel blong Turism blong Saot Pentikos (Tourism Council of South Pentecost, which ironically he had set up) and by Jif Telkon, his erstwhile collaborator and business partner. That case occasioned a dispute about intellectual property rights put to the Malvatumauri and Luke Fargo was ordered to pay 100,000 vatu (US $\$ 1,058)^{14}$ and several pandanus textiles for attempting this internal export of the gol. ${ }^{15}$

Since tourist land dives performed by people from the kastom villages of the southeast were first initiated in the early 1970s, Jif Telkon was one of the main beneficiaries of the revenue from such performances and payments from foreign filmmakers during the annual season between April and June. Lipp suggests that he was demanding US $\$ 25,000$ for filming a single land dive in the southeast, a more remote, 'exotic' and thus more expensive location than the west coast. ${ }^{16}$ But he was not the only one. There were and are many rival male entrepreneurs in Christian villages, especially on the more accessible west coast, as Lipp documents in detail, ${ }^{17}$ and as I witnessed

13 John Seale (director), 1990, Till There was you, written by Michael Thomas.

14 All conversions are as at 26 January 2014, rather than contemporaneous.

15 Miranda Forsyth, 2012, 'Lifting the lid on "the community": Who has the right to control access to traditional knowledge and cultural expression', International Journal of Cultural Property 19: 1-31.

16 Pigliasco and Lipp, 'The islands have memory', p. 393. He also observes that Jif Telkon was the major recipient of 600,000 vatu for the making of the documentary soapie The Bunlaps.

17 Thorolf Lipp, 2008, Gol. Turmpsingen auf der Insel Pentecost in Vanuatu. Beschreibung und Analyse eines riskanten Spektakels (Gol: Land Diving on the Island of Pentecost in Vanuatu: A Description and Analysis of a Risky Spectacle), Berlin: Lit Verlag, p. 266 ff. 
on a visit to Pentecost in April 2013: near the airport at Lonorore, at Panngi, Panlimsi, Randoa, etc. Some say Jif Telkon passed the knowledge of the land dive originating in the sacred site of Rebrion near Bunlap village to Luke Fargo. ${ }^{18}$ But there is also evidence of far earlier entrepreneurial activity from the 1950s to sell the spectacle as a commodity for foreigners and tourists on the part of influential men from the Anglican and Church of Christ villages from the south and west coasts. ${ }^{19}$

The extraordinary sequence of events in 2009 surrounding the Munich gol followed the untimely death of ni-Vanuatu cameraman Hardy Ligo, filming the gol in South Pentecost for National Geographic in 2008. On that occasion, the tower collapsed under the weight of the film crew and heavy equipment and three other South Pentecost men were killed or seriously injured..$^{20}$ This happened despite a moratorium imposed on such filming of the gol by the Vanuatu Cultural Centre (VKS) in 2006; it seems this was regularly ignored or circumvented. ${ }^{21}$ So, performing the land dive has become a very risky business, in both Pentecost and foreign locales. Although the element of male risk-taking and youthful daring has long been an integral aspect of the ritual, its reconfiguration as a tourist commodity and as contested intellectual and cultural property has amplified those risks enormously, through a spiralling vertigo of contesting masculinities.

18 Forsyth, 'Lifting the lid on "the community", p. 18; Murray Garde, 2015, "“Stories of long ago" and the forces of modernity in South Pentecost', in Narrative Practices and Identity Constructions in the Pacific Islands, ed. Farzana Gounder, pp. 133-52, Amsterdam: John Benjamins, Studies in Narrative series.

19 Lipp, Gol. Turmpsingen auf der Insel Pentecost in Vanuatu, p. 266.

20 Margaret Jolly, fieldwork notes, April 2013.

21 As Tabani reports since Ligo was a ni-Vanuatu TV cameraman, the VKS moratorium did not apply to him. He reports, allegations that Ligo was bribed to film the gol by the Australian production company Beyond Productions acting on behalf of the National Geographic Society. See Marc Tabani, 2010, 'The carnival of custom: Land dives, millenarian parades and other spectacular ritualizations in Vanuatu', Oceania 80(3): 309-28, p. 326n15. 
TOURING PACIFIC CULTURES

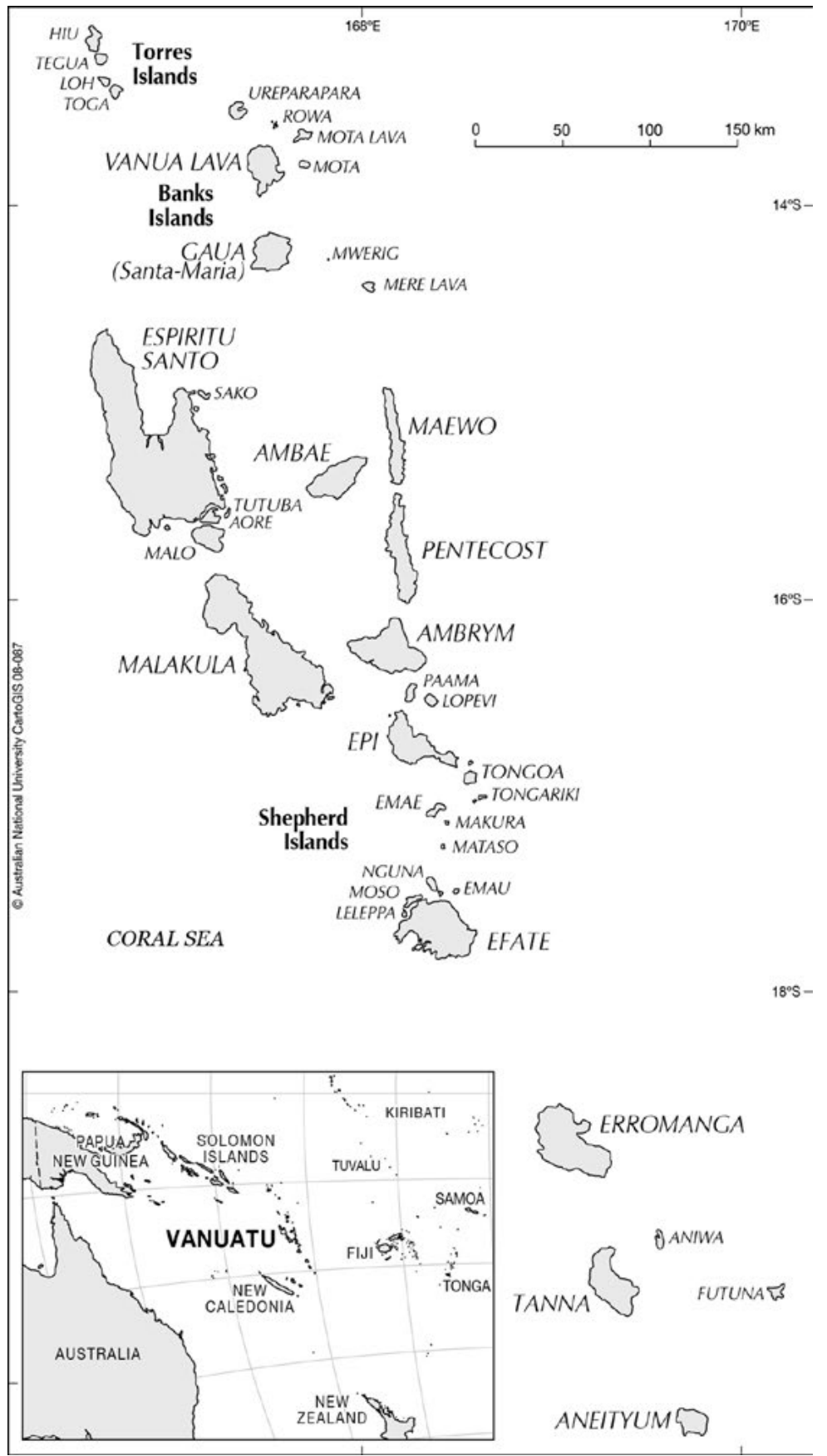

Map 2. Vanuatu and inset in relation to Australia.

Source. (c) Australian National University Cartography, CartoGIS 08-087. 
12. MOVING TOWERS

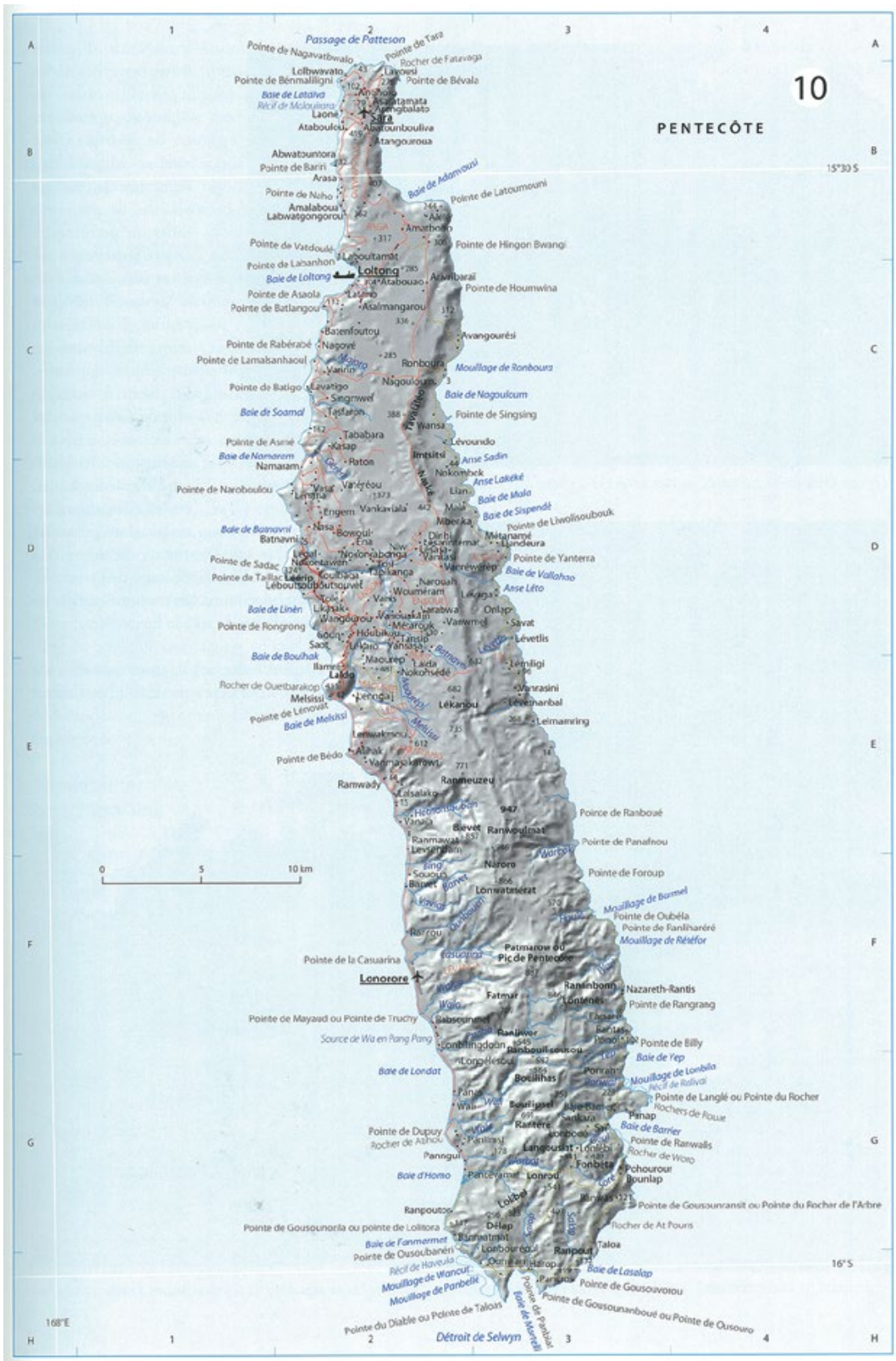

Map 3. Pentecost Island showing villages.

Source. Patricia Siméoni, 2009, Atlas du Vanouatou (Vanuatu), Port Vila: Éditions Géo-consulte, p. 49 and used with permission. 


\section{Ambivalences}

I must confess to a deep-seated ambivalence about the gol. This ambivalence has its origins deep in my formation as a feminist anthropologist. As a young woman conducting doctoral research in the kastom communities of the southeast from the early 1970s, I relished living with these feisty, anti-colonial and anti-Christian folk. ${ }^{22}$ But at first I was humiliated by the contrast powerful male leaders such as Telkon's late elder brother Bumangari Kaon, better known as Bong, made between myself, seemingly a young, weak, white woman from Australia, and Kal Muller, a strong, mature man and filmmaker from that mythical country, America, who had lived in Bunlap for some months just before my arrival in 1970. He had not only made a film (the profits of which were promised to be locally shared, yet proved elusive) but he was the first white man to jump from the tower, wearing the pipis, the pandanus penis wrapper, a sign of strong men of kastom. That spectacle was revealed in his article in National Geographic. ${ }^{23}$

When I walked with scores of kastom people from several villages in the southeast for the erection of one of the first towers for tourists near Lonorore airport in 1972, like all local women I was forbidden to see the tower being constructed (a ban that I noticed did not extend to short-haired female tourist agents from Port Vila). But, in a classic backhander, I was assured by my adopted father that this was because, speaking the language so well, I was now an êsên na ôt lo, a woman of the place. 'How would you feel Margaret if your brother fell from the tower?'24 Given these rather sensitive gender dynamics during my doctoral research, and my disquiet about the early impacts of commoditisation of the gol as a tourist spectacle, it is perhaps understandable that I did not share the ebullient enthusiasm of some male observers: tourists, filmmakers, anthropologists. ${ }^{25}$

22 Relations have changed since to a more ecumenical ethos and kastom people might now be better described as non-Christian rather than anti-Christian.

23 Kal Muller, 1970, 'Land diving with the Pentecost Islanders', National Geographic 1138(6): 796-817.

24 See Margaret Jolly, 1994, 'Kastom as commodity: The land dive as indigenous rite and tourist spectacle in Vanuatu', in Culture - Kastom - Tradition. Developing Cultural Policy in Melanesia, ed. Lamont Lindstrom and Geoffrey White, pp. 131-44. Suva: Institute of Pacific Studies, University of the South Pacific, p. 143n5.

25 See Margaret Jolly, 1994, Women of the Place: Kastom, Colonialism, and Gender in Vanuatu, Philadelphia: Harwood Academic Publishers; Jolly, 'Kastom as commodity'. 
Most of my knowledge about how the tower is constructed is thus derived not from observation or participation, which is possible only for men, but from conversations with local men and women and from several foreign men who were able to witness it: François Le Fur in $1902,{ }^{26}$ Elie Tattevin,${ }^{27}$ a Marist priest of the early twentieth century, Kal Muller in the $1960{ }^{28}$ and most recently in extraordinary detail Thorolf Lipp, in his book Gol das Turmspringen auf der Insel Pentecost in Vanuatu. ${ }^{29}$ I will not attempt here to offer the details of how the gol has changed historically, nor the complexities of Lipp's rather provocative exegeses and critiques of all those who have interpreted the gol in the past and his own uncertain conclusion that it is primarily a risky spectacle, a game more than a ritual. ${ }^{30}$ However, I agree with him that the $\mathrm{gol}$ is a multi-layered phenomenon that defies facile interpretations of it as a compulsory initiation rite or a necessary display of youthful masculinity. Here I rather pursue some earlier thoughts apropos how performances of the land dive evince relational masculinities, ${ }^{31}$ historically changing and contested, among indigenous men and between indigenous men and foreign men. This is inseparable from how kastom has become commodified and converted into 'property', intellectual or cultural, and the fact that custodianship is increasingly seen less as a collective heritage, and more as the 'ownership' of individual powerful men, who promote their chiefly rights to control. ${ }^{32}$

\footnotetext{
26 Paul Monnier, 1991, L'eglise catholique au Vanuatu. Port Vila: Mission Mariste, p. 15.

27 Élie Tattevin, 1927, 'Sur les bords de la mer sauvage', Revue d'Histoire des Missions 4: 82-97, 407-429, 557-59; Élie Tattevin, 1929, 'Mythes et Légendes du Sud de I'île Pentecôte', Anthropos 24: 983-1004; Élie Tattevin, 1931, 'Mythes et Légendes du Sud de I'île Pentecôte', Anthropos 26: 489-512, 863-81.
}

28 Kal Muller, 1970, 'Land diving with the Pentecost Islanders', National Geographic 1138(6): 796-817; and Kal Muller, 1971, 'Le Saut du Gaul dans le sud de l'île de la Pentecôte, NouvellesHébrides', Journal de la Societe des Oceanistes 32: 219-234.

29 Thorolf, Gol. Turmpsingen auf der Insel Pentecost in Vanuatu. I am indebted to Sabine Hess who completed an abbreviated translation and a distillation of the main content of this book in 2012.

30 I simply observe that in his tables summarising previous approaches it is hard to reconcile his telegraphic exegeses with the arguments presented by the authors. See Lipp, Gol. Turmpsingen auf der Insel Pentecost in Vanuatu, pp. 36 and 396.

31 Jolly, 'Kastom as commodity'; Margaret Jolly, 2008, 'Introduction. Moving masculinities: Memories and bodies across Oceania in Re-membering Oceanic Masculinities', The Contemporary Pacific 20(1): 1-24.

32 See Siobhan McDonnell, 2013, 'Exploring the cultural power of land law in Vanuatu: Law as a performance that creates meaning and identities', in Grounding Travelling Concepts: Dialogues with Sally Engle Merry about Gender and Justice, ed. Hilary Charlesworth and Margaret Jolly, Intersections: Gender and Sexuality in Asia and the Pacific, issue 33; Siobhan McDonnell, 2016, 'My land my life: Power, property and identity in land transformations in Vanuatu', PhD thesis, The Australian National University. 


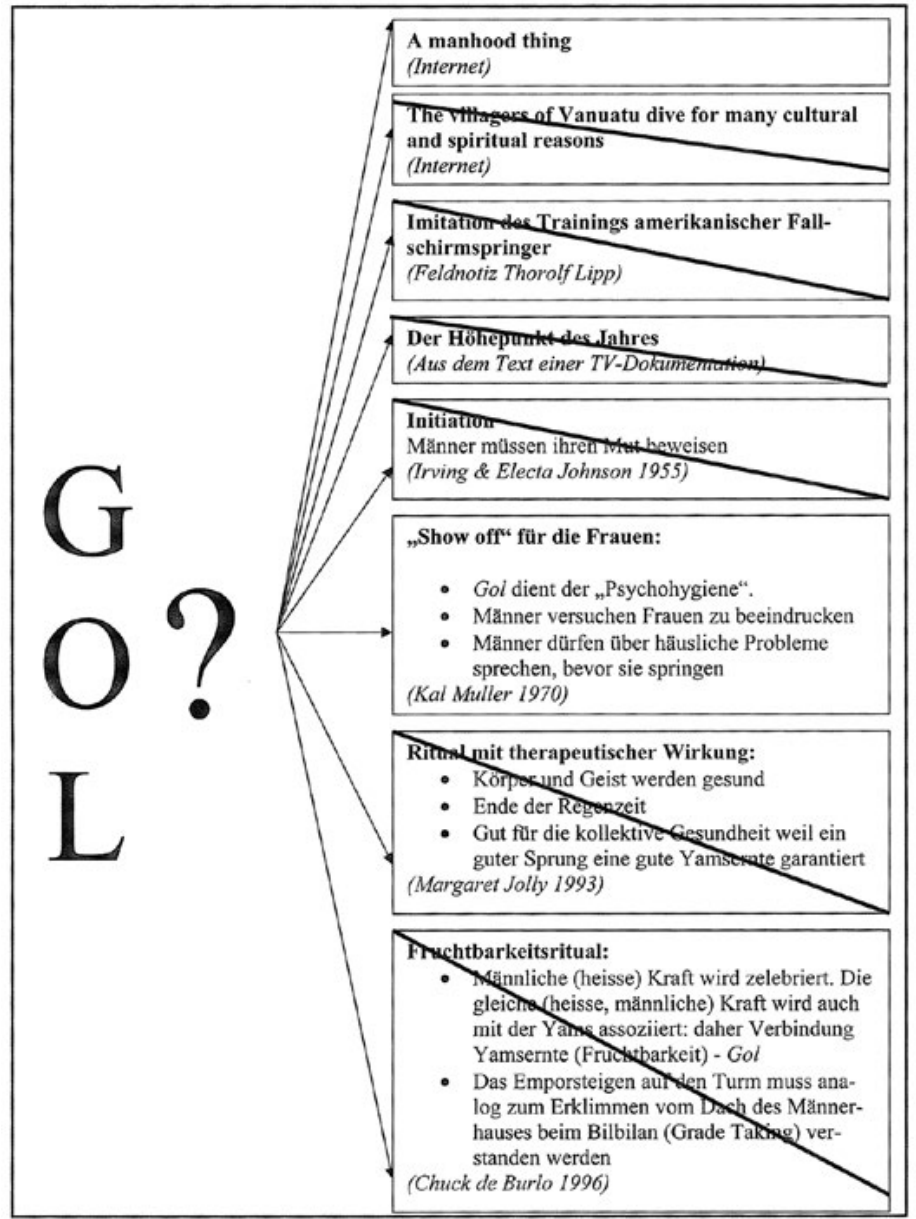

Figure 63. Lipp's table expounding and critiquing earlier approaches. Source. Lipp, 2008, Gol. Turmpsingen auf der Insel Pentecost in Vanuatu, table 30, p. 396.

\section{Dun na ngamômô: The origin of gol}

To explain most kastom practices in South Pentecost - the origin of life and of death, of sexual difference, the separation of the household dwelling and the men's house-outsiders and anthropologists, like young children, are usually told a dun na ngamômô a 'story of long ago'. ${ }^{33}$ These stories are typically performed by older people,

33 Garde, "Stories of long ago" and the forces of modernity in South Pentecost'. 
men and women, and are usually punctuated with poignant songs, in both everyday and archaic exotic/language, led by the main storyteller who is then joined in chorus by the surrounding audience. These are both didactic and immensely pleasurable shared aesthetic experiences. ${ }^{34}$ A pivotal story in the rich Sa corpus of verbal arts is the dun na gol: the story of land diving, which explains why men engage in such an arduous construction every year and jump from its dizzying heights with only lianas tied to their ankles.

As Lipp records ${ }^{35}$ and Garde consummately analyses, ${ }^{36}$ there is not one story but several versions, indeed several competing stories of the origin of the land dive. ${ }^{37}$ Yet the gendered dynamics of the land dive are palpable in all versions. Here is a telegraphic summary of a short, simple version:

34 See Margaret Jolly, 1999, 'Another time, another place', Oceania 69(4): 282-99; Margaret Jolly, 2003, 'Spouses and siblings in Sa stories', The Australian Journal of Anthropology 14(2): 188-208. Let me here briefly lament that Lipp fails to acknowledge either of these papers, in which I consider not just the diversity of versions of $d u n$ but historical transformations in origin stories collected by Tattevin and myself. See Lipp, Gol. Turmpsingen auf der Insel Pentecost in Vanuatu. For excellent studies from PNG see Alan Rumsey and Don Niles (eds), 2011, Sung Tales from the Papua New Guinea Highlands: Studies in Form, Meaning, and Sociocultural Context, Canberra: ANU E Press.

35 Lipp, Gol. Turmpsingen auf der Insel Pentecost in Vanuatu, p. $303 \mathrm{ff}$.

36 Garde, "Stories of long ago" and the forces of modernity in South Pentecost'.

37 Murray Garde discerns the following elements in all versions of dun na gol:

1. a husband and wife were in an unsatisfactory relationship

2. after much disputation the wife flees

3. the husband pursues the wife and she climbs up a tall tree

4. the husband follows her up the tree

5. the woman ties vines/aerial roots/coconut palm leaf fibre around her ankles

6. when the husband lurches to grab her she jumps out of the tree

7. the husband falls and with nothing to restrain him, he hits the ground and dies but the woman is saved by her vines

8. others reflect on how the woman was saved and they copy her.

See Garde, "'Stories of long ago" and the forces of modernity in South Pentecost', pp. 3-4.

There are also many variations based on region and on the speaker. See Garde, "'Stories of long ago" and the forces of modernity in South Pentecost'; Lipp, Gol. Turmpsingen auf der Insel Pentecost in Vanuatu. Some specify that the wife feels pain in sex, is held against her will or beaten by the husband; some specify that the husband is lazy or deformed. Some versions detail a banyan tree and liana restraints; others a coconut tree and palm leaf ties. In condensed versions the husband simply falls and dies; in other fuller versions (often told in kastom villages in the southeast, as in Telkon's long version of September 2012), the wife brings him back to life to satisfy her desires, whipping each successive part of his body in turn, and singing a song that revives him even, in some versions, reanimating his penis, ensuring a more fulfilling domestic life. The concluding credo varies too: sometimes men usurp control so that women do not expose their genitals jumping in grass skirts, which fly upwards; sometimes it is claimed that having outwitted men, women rather handed over this clever ploy. In the version told by Jif Telkon Watas, he declared that women insisted that the sign of its female origins should remain in the 'lips of the vagina', which is a crucial part of the supporting wooden struts for each platform. 
A woman was living with her husband Tamlie but found his sexual desires excessive and violent. She decided to leave him and climbed a banyan tree to escape. He zealously pursued her up the tree. She tied lianas around her ankles and, as he reached out to grab her, she jumped and saved herself. He jumped after her but, with no restraints, he hit the ground and died. Men telling this version often conclude, 'Since then things have been the right way up, men jump from the tower and women dance in adoration underneath.'

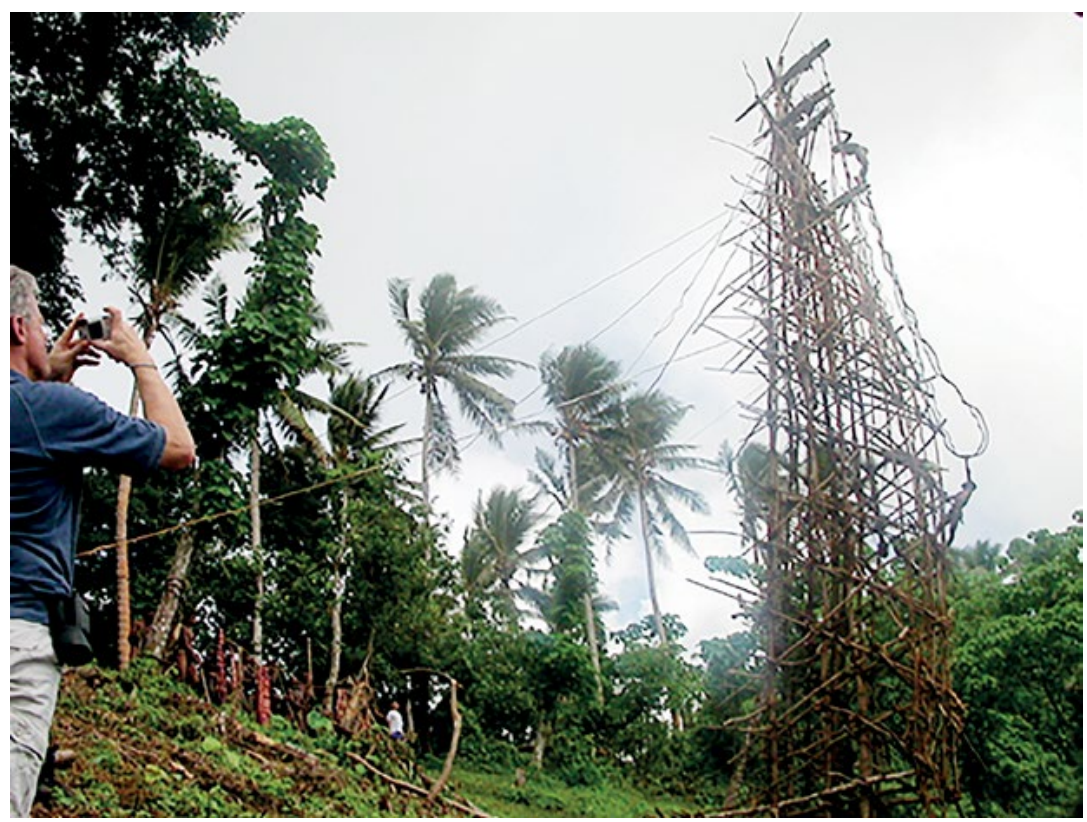

Figure 64. Gol-tapering to the top or 'head' of tower.

Source. Photographed by Murray Garde, Wali, south-west Pentecost, 5 June 2004.

Gol refers to both the tower itself and the performance of the dive. The tower is usually between 20-30 metres high, made of logs in a lattice construction and, as constructed in Bunlap (gol abri), tapering at the top. Lipp argues that the dominant form in the past as recorded by Tattevin was built around the trunk of a large tree. ${ }^{38}$ The ground around the tower should be sloping and is cleared and sifted scrupulously of hard objects, readying it for the tower to grow, and men to dive, just as the ground is sifted for the planting of long yams. Diving platforms are added at successive heights. 
The tower is conceived of as a human body (although gol is not the word commonly used for the body, which is rather tarben; the whole tower can be called tarbe gol). ${ }^{39}$ The tower has legs and knees, a belly, breasts, neck, shoulders, armpits and a head. I was told by several men that it embodied the spirit of an ancestor. Some said it was Tamlie, that hapless first male diver. Others said it was Sêngêt from whose body different kinds of yams emerged: long yams from his back, protuberant yams from his fingers, red yams from his blood. ${ }^{40}$ Yet despite a resident male spirit, sensed in the crackling noises of the tower and tinglings on the skin of the divers, the gol is manifestly a bisexual body. The different parts of its several diving platforms are sexually differentiated: the central log is the shaft of the penis, the surrounding supports, the lips of the vagina.

Young boys and younger men dive from the tower at successive heights. There is no compulsion for men to perform the land dive, it is a matter of personal preference and, as both Lipp and I attest, ${ }^{41}$ many high-ranking and powerful men have not. In my experience, there is no shame in not jumping, even if the diver comes to the end of the platform and then decides not to jump (although more recently other observers have noted some tough persuasion if not coercion of young boys). But the jump should be a graceful swallow dive, head first and with arms held tight to the chest and body well clear of the tower. On the higher levels, other men can help the diver by ensuring his ropes are not caught, impeding a smooth dive. The divers are freed from their hanging lianas by older men, often fathers or brothers, who check to see they are not hurt, embrace them and celebrate a successful leap.

39 A linguistic note from Murray Garde. 'It is interesting that in the case of the gol tower, you can use the human third person singular possessor tarbe- $n$ "its body" because the tower is given human-like status.' If it were thought of as a tree it would rather be: tenlê bôtôa 'trunk of a tree'. Email to author 16 February 2015.

40 Jolly, Women of the Place, p. 66; see Telkon Watas and Murray Garde, 2012, Dun na gol, transcribed and translated by Murray Garde, filmed by Kim McKenzie, September. In Jif Telkon Watas's story, senget is not a proper name of a male ancestor but the generic word for a person covered in sores with rotting fingernails (perhaps a reference to the skin condition psoriasis or, my editor Jack Taylor suggests, an old decaying yam?).

41 Lipp, Gol. Turmpsingen auf der Insel Pentecost in Vanuatu; Jolly, Women of the Place, p. 242. 
TOURING PACIFIC CULTURES

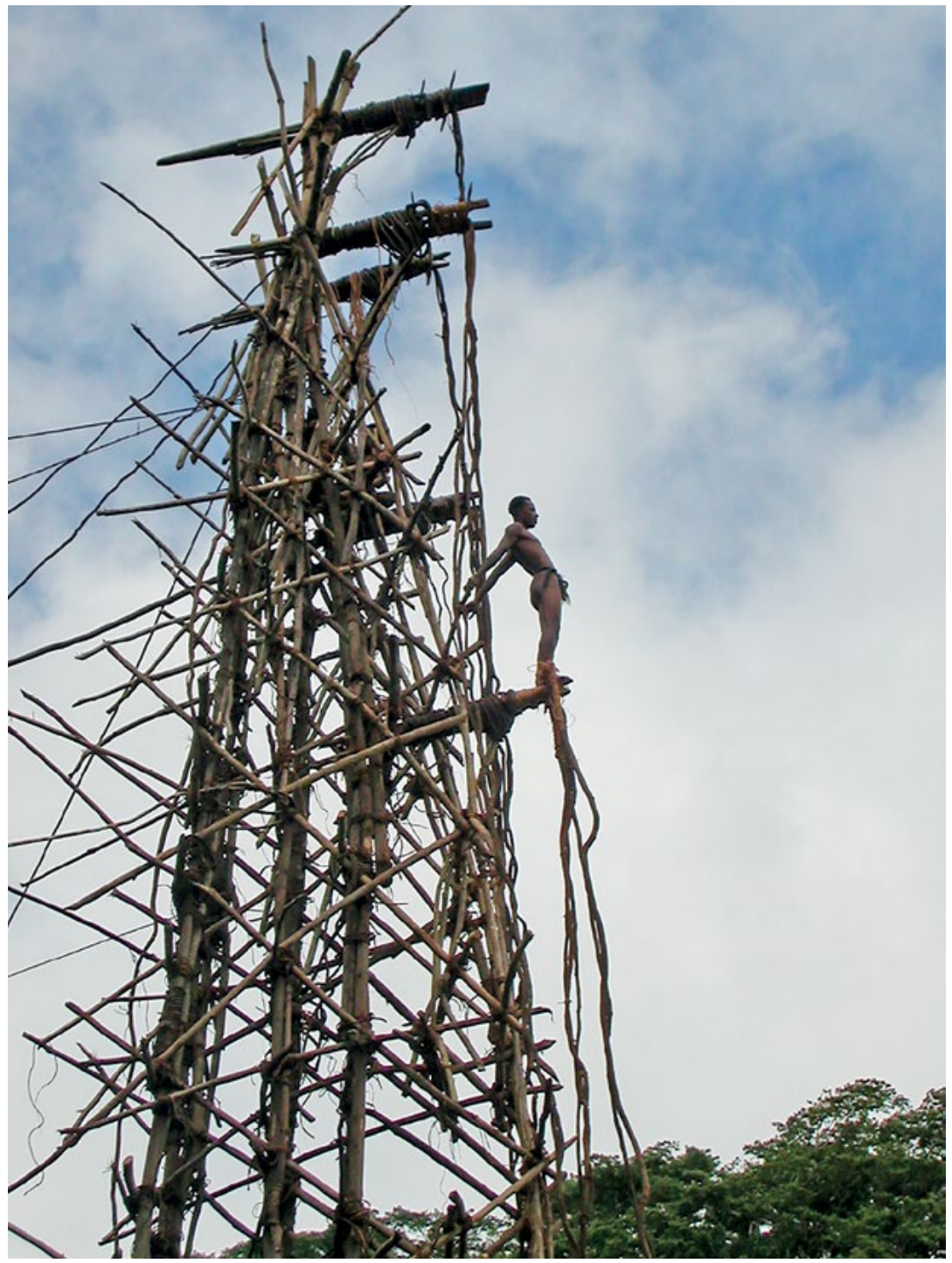

Figure 65. Gol-a diver poised to jump from the middle of the tower. Source. Photographed by Murray Garde, Wali, South Pentecost, 5 June 2004. 


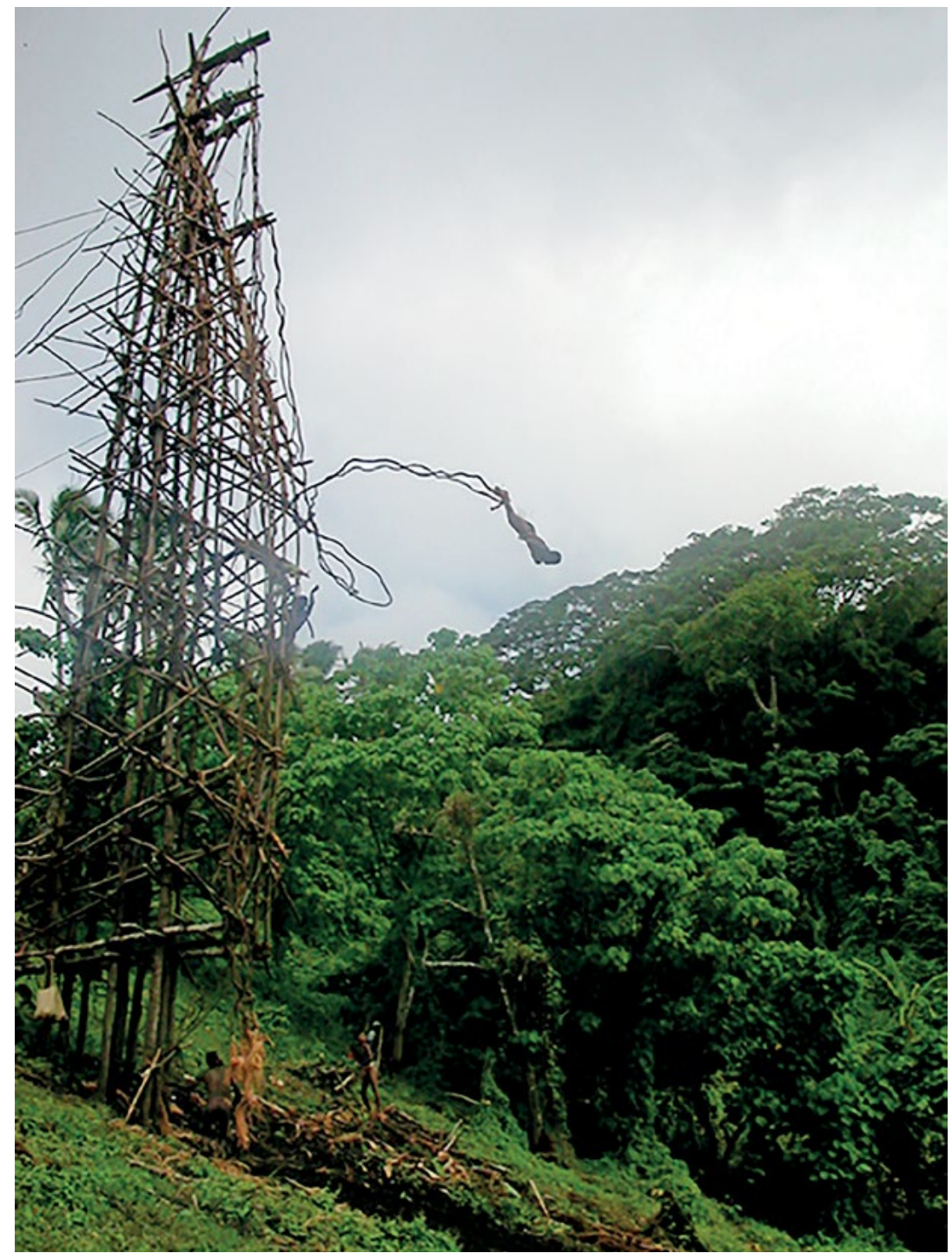

Figure 66. Gol-a diver in full flight.

Source. Photographed by Murray Garde, Wali, South Pentecost, 5 June 2004.

This is a spectacle primarily directed at the men and especially the women who are dancing underneath. Women are forbidden to see the tower until its construction is complete and the spirit inhabits its body. Men must refrain from sexual relations with wives or lovers before they dive, or risk their platform breaking and their lianas snapping. But the presence of women is crucial to the final spectacle: 
dressed in their best white grass skirts made of banana spathe rather than pandanus, with perfumed leaves adorning their bodies, they perform dances of celebration after each successful dive, sometimes mothers and sisters (but never wives), embracing divers as they touch the ground, cradling croton leaves and towels as if they were surrogate babies, chanting and whistling loudly, in a piercing style, uncannily like a wolf whistle. These are beautiful black male bodies on display, and diving evinces not just their athletic power and courage but their sexual appeal to women, their virility and fertility.

Despite Lipp's attempt to disarticulate the land dive and the yam harvest, ${ }^{42}$ I am persuaded that there is a crucial link between the two, at least for kastom people. Indeed, this was stressed by all my interlocutors and is a central motif in the long epic version of the dun na gol, as performed by Jif Telkon Watas for Murray Garde and the late filmmaker Kim McKenzie in September 2012. In this instance, clutching a yam as a prop, Jif Telkon Watas declared and then repeated that, 'the land dive was created in relation to yams'. ${ }^{43}$ The yam cycle still structures the Sa calendar in South Pentecost (even now when the dry seems to be starting later; as people told us during a very wet April in 2013 - klaemet $i$ jenis (the 'climate is changing')). The tower is built when the yams are ready to harvest and the lianas are drying out. This ensures that the vines have the right springy tensility to hold the diver and ensure he does not rebound too far and hit the body of the tower. Indeed kastom people in the southeast are to this day critical of their Christian kin on the west coast who start tourist land dives too early, before yams have been ritually harvested, and blame the increase in injuries and accidents on reckless disregard of these rules and the pursuit of profit. ${ }^{44}$

42 Lipp, Gol. Turmpsingen auf der Insel Pentecost in Vanuatu, p. 396.

43 Garde, "Stories of long ago" and the forces of modernity in South Pentecost'; Watas and Garde, Dun na gol.

44 This is highlighted in Telkon's epic version: 'If you do not respect the part that the yams play, you will be injured.' This seems to suggest that the yams themselves are animated agents that can harm. As Garde notes, this means waiting to harvest the yams first. This is usually done by the loas na dam, the yam specialist who has the expertise to initiate the harvest with spells and magical techniques. For five days after this no one can leave or enter the village. Murray and I were subject to this stricture on our visit to Bunlap in April 2013, and waited on the west coast at Baie Homo till we could safely walk in. Then the cutting of the timber for the towers should follow, 10 days after the new moon in April. These strictures are not followed so closely by Christian people and thus the critical link to yams is not made. See Garde, "“Stories of long ago" and the forces of modernity in South Pentecost', p. 10. 
During my doctoral research I was told that, despite the obvious real risks of concussion, injury and death, diving was masculine bodily therapy after the aches of the rainy season. The yam is the canonical symbol of the male body and especially the penis in the competitive cultivation of the long yam, dam bis. There is an intimate connection in myths and this ritual between long, strong yams and men's fertile bodies. Like the grade-taking rituals in which both men and women can rise in rank, assuming higher titles, it is a prime occasion for young men to impress young women with their beauty and strength. Some men in pursuit of particular lovers whisper love magic before they dive and drop special leaves that they hope their desired partners will catch.

But, the spectacle of masculinity that is on display in gol is a fiery, hot, youthful masculinity, evincing the muscular athleticism and the power to take risks that was epitomised in the past by young warriors or bwari. The frequent internecine raids and battles that prevailed in South Pentecost up until the 1920s were ended by that process of colonial conquest paradoxically called 'pacification'. Without suggesting a functionalist hydraulics of male fluids, ${ }^{45}$ I suggest that some of the energies and values of masculinity associated with warfare in the past have flowed into the gol. But this is not the most privileged or hegemonic form of masculinity. ${ }^{46}$ That was and is associated rather with the cool wisdom of the peacemaker, the warsangul, the highranking man, or the jif (chief) who can mediate and settle disputes. These opposed but hierarchically structured figures - 'men of war' and 'men of peace' ${ }^{47}$ - were in the past linked with seasonal cycles (while taking titles there should be no wars and vice versa), echoing the alternating powers of the God of War (Kū) and the God of Peace (Lono) in Hawai'i. In South Pentecost, men of peace typically eclipsed men of war.

45 See Margaret Jolly, 2001, 'Damming the rivers of milk? Fertility, sexuality, and modernity in Melanesia and Amazonia', in Gender in Amazonia and Melanesia: An Exploration of the Comparative Method, ed. Thomas A. Gregor and Donald Tuzin, pp. 175-206, Berkeley: University of California Press.

46 See R.W. Connell and James W. Messerschmidt, 2005, 'Hegemonic masculinity: Rethinking the concept', Gender and Society 19(6): 829-59.

47 See Margaret Jolly, 1991, 'Gifts, commodities and corporeality: Food and gender in South Pentecost', Canberra Anthropology 14(1): 45-66; Jolly, Women of the Place; and Margaret Jolly, 2016, 'Men of war, men of peace: Changing masculinities in Vanuatu', in Emerging Masculinities in the Pacific, ed. Aletta Biersack and Martha Macintyre. The Asia Pacific Journal of Anthropology, 17(3-4): 306-323. 
TOURING PACIFIC CULTURES

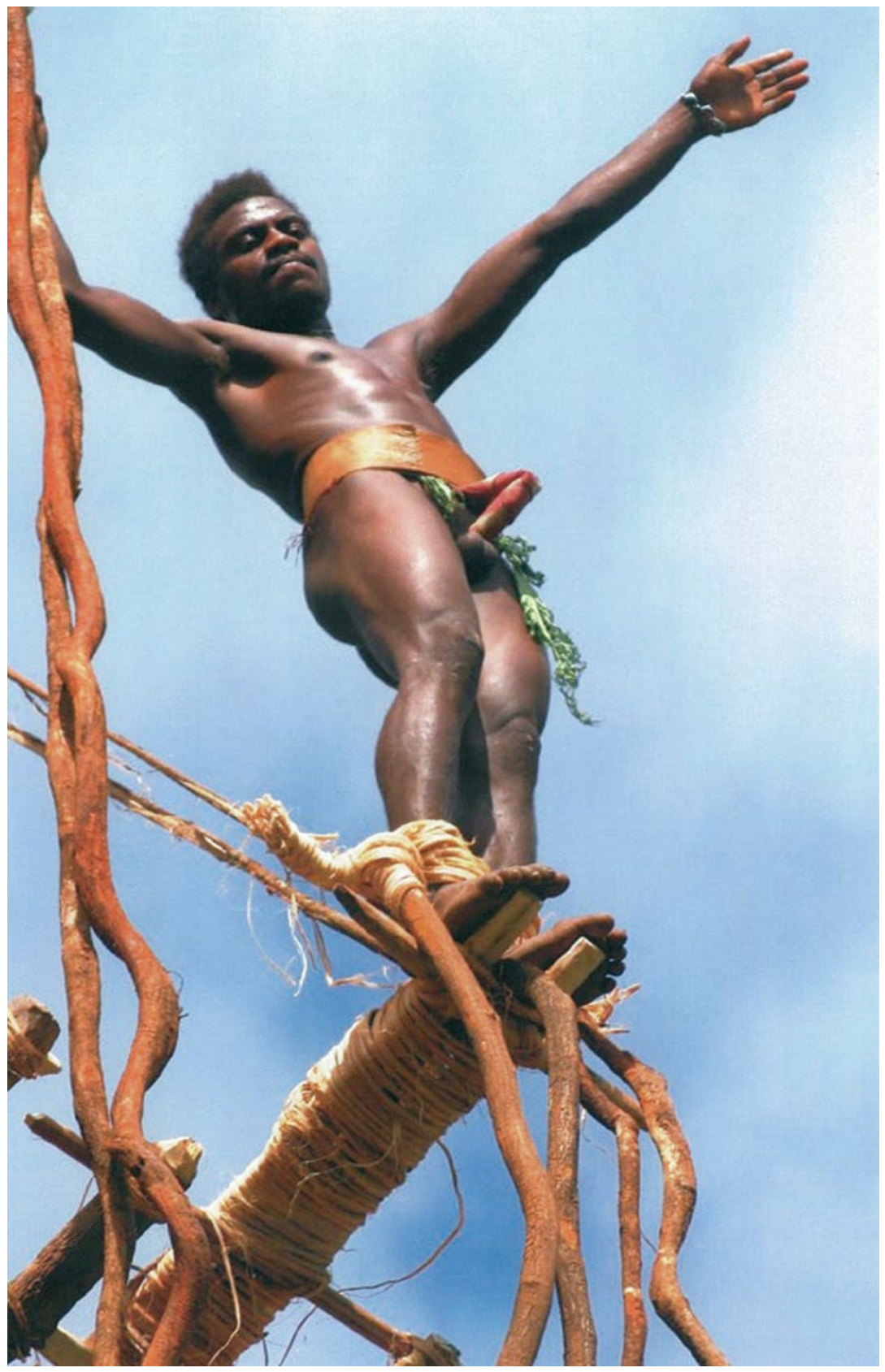

Figure 67. A young man wearing a penis wrapper and bark belt about to dive, epitomising hot, youthful masculinity

Source. Photographed by John Taylor, Pentecost, 9 June 2007. 


\section{Colonial reconfigurations: The French Resident Commissioner and Queen Elizabeth II}

Clearly the indigenous significance of the gol has radically changed over the century or more from when it was first witnessed by the Marist priests like Elie Tattevin in the early twentieth century. ${ }^{48}$ But the most profound transformations derive from its performance as a tourist spectacle from the early 1970s. In the past only a few towers were built each year, the gol was produced for internal consumption and then destroyed and used for firewood. Today, despite attempts both by the VKS and local authorities to restrict the number of gol to a few per season, there may be 20 or 30 performed at several rival sites during the dry season from April through June, where the audience is primarily paying tourists, filmmakers and anthropologists, and where the tower is sometimes recycled for later performances. I have earlier traced the origins of this commoditisation of kastom to two critical events in the colonial period, both of which reveal crucial gender dynamics at work. ${ }^{49}$

The first is described both in oral history and documents in the colonial government archives. In 1952, there was a rumour spread by a Church of Christ convert that a 'cargo cult' was spreading amongst the kastom adherents of Bunlap and adjacent villages. ${ }^{50}$ The conjoint colonial authorities were so fearful of a violent anti-colonial revolt that they dispatched both British and French troops who made a nocturnal raid on Bunlap. They thought they saw signs of preparation for war but rather witnessed arrangements for a major grade-taking

\footnotetext{
48 Following Lipp, Tabani, notes the transformation over several decades from the form described by Tattevin where branches of a banyan tree served as diving platforms to the construction of a tower in gol abwal. See Lipp, Gol. Turmpsingen auf der Insel Pentecost in Vanuatu; and Tabini, 'The carnival of custom', p. 321. Tabini speculates that the towers constructed by the American forces to train parachutists in World War II may have been a model for the latter form. Though Lipp rejects this hypothesis as tourist gossip (pp. 395-96), Tabani insists that the speculation needs to be seriously considered. Certainly Lindstrom and Tabani have both shown how ritual spectacles now indigenous to Tanna have been dramatically shaped by external influences and especially the American presence, most notably the pervasive drilling, the red cross and the telegraph wires of the John Frum movement in its several manifestations.

49 Jolly, 'Kastom as commodity'.

50 Jolly, Women of the Place, pp. 45-48.
} 
ritual. ${ }^{51}$ They arrested several old men, including Meleun Tamat, the father of Bumangari Kaon (Bong) and Liusbangbang (Telkon Watas), and imprisoned them in a copra dock at the Catholic mission station of Baie Barrier. Several younger men offered themselves in lieu of their fathers, and were later imprisoned in Port Vila. Some say that the man who spread the rumour confessed that he did so in order to get kastom people to convert and the young men were thus freed and he was rather imprisoned. Others say the then French Resident Commissioner Pierre Anthonioz offered that their sentences be commuted if these young men organised a land dive for him to watch..$^{52} \mathrm{~A}$ gol was built and performed and the divers were paid three blocks of stick tobacco in recompense. This important historical event was recalled in a chant I heard sung in the 1970s at land dives, the words of which celebrated the power of black men over white men.

The second is a story circulated locally and on the internet about the performance of the gol for Queen Elizabeth II on 16 February 1974. ${ }^{53}$ At the urging of the British colonial administration, the people of Point Cross, a village of Anglican adherents of the Melanesian Mission, agreed to perform the gol for the royal visit. This was organised by Kiliman, who in this instance refused to allow a performance in Port Vila and required the Queen to come to Pentecost. Despite this insistence, it was still the wet season, and the lianas were too slack. One diver from Point Cross was desperately unlucky; both his lianas broke, he fell and broke his back and later died in hospital. There was intense speculation about the causes of this tragic occurrence. Some said the diver had slept with his girlfriend the night before, and was thus cursed. The dominant explanation in Bunlap, however, was that this was a sign of the incapacity of weak Christian men to perform

51 In his report of this event, Tabani observes, based on a conversation with me, that it was a 'Warsangul initiatory ceremony during which very large quantities of goods are ostentatiously accumulated'. See Tabani, 'The carnival of custom', p. 313. I would, however, like to clarify this issue, as this is a curious representation of what I said; warsangul ceremonies are not initiations but rather entail men and women taking titles and though they involve display and exchanges of taro and tams, pigs and pandanus titles, they do not occasion 'ostentatious accumulation'. For a detailed description of such ceremonies, see Jolly, Women of the Place, p. 173ff.

52 See Pierre Anthonioz, 1953, 'La danse du Gaul dans le sud de l'île de Pentecôte', Mission des isles 46: 6-7; Pierre Anthonioz, 1954, 'La danse du Gaul, céremonie rituelle de l'île Pentecôte', Etudes Mélanésiennes 8: 92-95.

53 I must apologise for an error in the date in earlier publications: Jolly, Women of the Place and 'Kastom as commodity'. Heartfelt thanks to my colleague Gregory Rawlings for pointing this out. The official record of Queen Elizabeth's visit to the New Hebrides is 15-16 February 1974. 
the gol: they said it was dangerously mistimed in the middle of the wet season and the men constructing the tower lacked the knowledge and technical expertise to build it properly, and to select appropriate lianas. This infamous incident therefore fuelled the already existing divisions between kastom and Christian peoples in the early 1970s. When I returned to Pentecost in 1977, following this incident, Bumangari Kaon shared his outrage with me, suggesting that it made the men diving appear like 'circus animals'.

\section{Cosmetic kastom and commodities}

But as I intimated in my paper 'Kastom as commodity'54 and Lipp records in fine detail, ${ }^{55}$ the history of Christians performing the gol is far more complex and varied than that suggested by oral historians in Bunlap. In fact, Oskar Newman, the Australian planter based at Malakula, hearing of the gol performed for Pierre Anthonioz by Bunlap men in 1952, commissioned a gol by men of Point Cross about 1955. In that instance, several New Zealand and Australian guests paid $£ 300$ each. Following the success of that event, around 1957 Newman commissioned a second when 40 Americans paid £500 each. Around the same time, in 1954, the American adventurers Electra and Irving Johnson filmed a land dive performed at Lonorore near the airport and Thevenin's plantation. In this instance, contrary to the current aesthetic of 'full kastom', the men can be seen wearing shorts. ${ }^{56}$ They also took about 1,600 still photographs. Some years later, in 1971, men from Point Cross performed a gol at Aligo in North Pentecost to raise funds for building a Melanesian Mission (Anglican) church in the south. This was three years before the notorious and tragic performance for Queen Elizabeth II.

The prior examples given above demonstrate that the gol was already being thoroughly 'worlded' in the immediate post-World War II period. The involvement of Christian and kastom villagers in gol oriented to outside guests and commercial purposes spread far more widely following the organisation and filming of a gol by Kal Muller

\footnotetext{
54 Jolly, 'Kastom as commodity'.

55 Lipp, Gol. Turmpsingen auf der Insel Pentecost in Vanuatu.

56 See Irving Johnson and Electra Johnson, 1955, 'South Seas incredible land divers', National Geographic January: 77-92.
} 
in Bunlap village in 1969. His film and a related National Geographic article converted the land dive into an international media spectacle, ${ }^{57}$ soliciting the involvement of tour companies, and the large upmarket hotel in Port Vila, Le Meridien. But there was a crucial difference in the land dive filmed by Muller. ${ }^{58}$ It not only involved a white man diving in a pipis, it also entailed the cosmetic recreation of an exotic, authentic kastom. No more shorts; men must wear only the pipis or penis wrapper with bark belts and women only their best ra is or grass skirts. Locals say he forbad women to carry towels or manufactured cloth (with which they often dance) and even tried to prevent women wearing safety pin earrings, a feminine fashion preference in South Pentecost long before the punk style fashionable in the US, UK and Australia in the 1970s. This cosmetic recreation of kastom was also adopted by those in Christian villages. They either hired people from the kastom villages to perform the dives, songs and dances, or else swapped their shirts and shorts and aelan dres for those iconic signs of kastom: the penis wrapper and the grass skirt. ${ }^{59}$ This is not without a sense of discomfort and even shame on the part of Christian villagers. In Bunlap in the 1970s, corrugated iron roofs (im kap) were forbidden and when such structures were later built in kastom villages they were often covered up with thatch or palm leaves for the eye of the tourist and the eye of the camera. ${ }^{60}$

In the decades since, complex patterns of both collaboration and rivalry have emerged between those in kastom and Christian villages. Kastom men from Bunlap led by Jif Telkon Watas reinstructed Christian men in the practice but also sought to hold their own gol in Christian villages on the west coast, which were far more accessible to tourists coming by boat or air. There was concern about Christians 'stealing' kastom

57 Muller, 1970, 'Land diving with the Pentecost Islanders'.

58 Tabani notes that Muller acknowledges he was looking for cultures scarcely touched by European civilisation, but fails to note the tension between the exclusion of all visible European influences and the fact of Muller himself participating in the rite, an enactment of going native that Tabani dubs 'a Hollywood fantasy worthy of Tarzan films'. See Tabani, 'The carnival of custom', p. 314.

59 See Margaret Jolly, 2014, 'A saturated history of Christianity and cloth', in Divine Domesticities: Christian Paradoxes in Asia and the Pacific, ed. Hyaeweol Choi and Margaret Jolly, pp. 429-54, Canberra: ANU Press.

60 On a French film team in Bunlap in 2002, see Lipp, Gol. Turmpsingen auf der Insel Pentecost in Vanuatu, p. 81; and on 'photogenic authenticity', see John Taylor, 2010, 'Photogenic authenticity and the spectacular in tourism', La Ricerca Folkorica, special issue Indigenous Tourism and the Intricacies of Cross-Cultural Understanding 61: 33-40. 
and having to share the profits, but the advantages were also clear. The collaboration between Jif Telkon Watas and Luke Fargo of Londot resulted in gol being performed at Panlimsi, Londot and Wali and near Panas on the west coast between 1976 and 1990. They collaborated but regularly fell out over money. Fargo established the Kaonsel blong Turism Blong Saot Pentikos in 1983, and was successively involved with several tourist agencies: Tour Vanuatu, Island Holidays and Island Safaris. There was also a revival of gol by Catholic villagers at Wanur in the south and in the villages north of Baie Barrier. Their remote location on a turbulent coast made tourist accessibility even more difficult than Bunlap, so they shifted to Rangusuksu on the west coast. But in many of these west coast land dives, kastom people were still hired for diving, dancing and singing.

In the early 2000s, when Lipp and Martina Kleinert spent five months in Bunlap, there were about 30 land dives per season, with several being performed at one site in successive weeks. There have been attempts both by the state through the VKS and by local associations to regulate the number of land dives per year. In 2011 there was a widely publicised dispute between the Kaonsel blong Turism Blong Saot Pentikos (South Pentecost Tourism Council), which planned 26 dives that year, and the Council of Chiefs of South Pentecost, who decided there should be just four. At this point Jif Telkon Watas was the chairman of the Council of Chiefs and claimed that only it had the customary authority in the matter. There are also material reasons for restricting the number of dives: in many locales the gol is only performed if there are sufficient bookings. The interests of filmmakers have also spiralled and many film crews have made movies both before and after the VKS moratorium of $2006 .{ }^{61}$

61 The moratorium was justified on the grounds of conserving the natural resources used for the dive, preserving the traditional knowledge and transmitting it to younger generations and promoting a co-ordinated plan whereby revenues generated by commercial activities were 'properly channelled into sustainable development appropriate to the needs of the communities of this region'. Vanuatu Cultural Centre website, www.vanuatuculture.org (accessed 4 May 2006). 
The gol has today become a lucrative and burgeoning business. Tourists pay a different price depending on context; some passengers on large cruise ships pay only about 2800 vatu (about US\$30) per person. But the shipping companies have had to pay millions of vatu for jetties, landing rights and the right to watch and film. Package deals for tourists travelling from Port Vila with return flights and an overnight stay cost 33,900 vatu (US\$359) in 2002, 38,900 vatu (US\$412) in 2004 and 47,600 vatu (US\$504) in 2006..$^{62}$ Filmmakers pay far more, for example a French team of seven filming in 2004 paid 1 million vatu (US\$10,526) for a two-week stay. Lipp and his partner Martina Kleinert paid 600,000 vatu (US\$6,316) to live in Bunlap and to film and photograph in 2002 and $2004 .{ }^{63}$ There are regularly disputes and scandals about the proportional distribution of this money between all participants: those who are the custodians of the land where the dive is held, the divers and the entrepreneurial organisers, like Jif Telekon Watas. The latter regularly commandeered the largest amount, although there have been attempts to change this and to direct the funds into projects of sustainable development such as water tanks and building projects. An association called PonWaHa was set up in Wanur with this in mind and ostensibly Bebe Malegel and his collaborators in Bunlap were striving for something similar. Another association 'Holding Nagol na Wawan Association' emerged from a meeting at Salap village in October 2008. This was expressly to debate issues about 'ownership' of the gol. ${ }^{64}$ Significantly, whereas in the period of my doctoral research the tower was usually named for the man who dived from its bôtôn/bwôtôn, or head (e.g. gol na Iya, gol na Watas), today the tower is more usually known by the name of the male entrepreneur who is the main organiser or 'boss' of the tower.

62 Lipp, Gol. Turmpsingen auf der Insel Pentecost in Vanuatu, pp. 294-95.

63 Ibid., p. 295.

64 Garde, "'Stories of long ago" and the forces of modernity in South Pentecost', p. 11. 
12. MOVING TOWERS

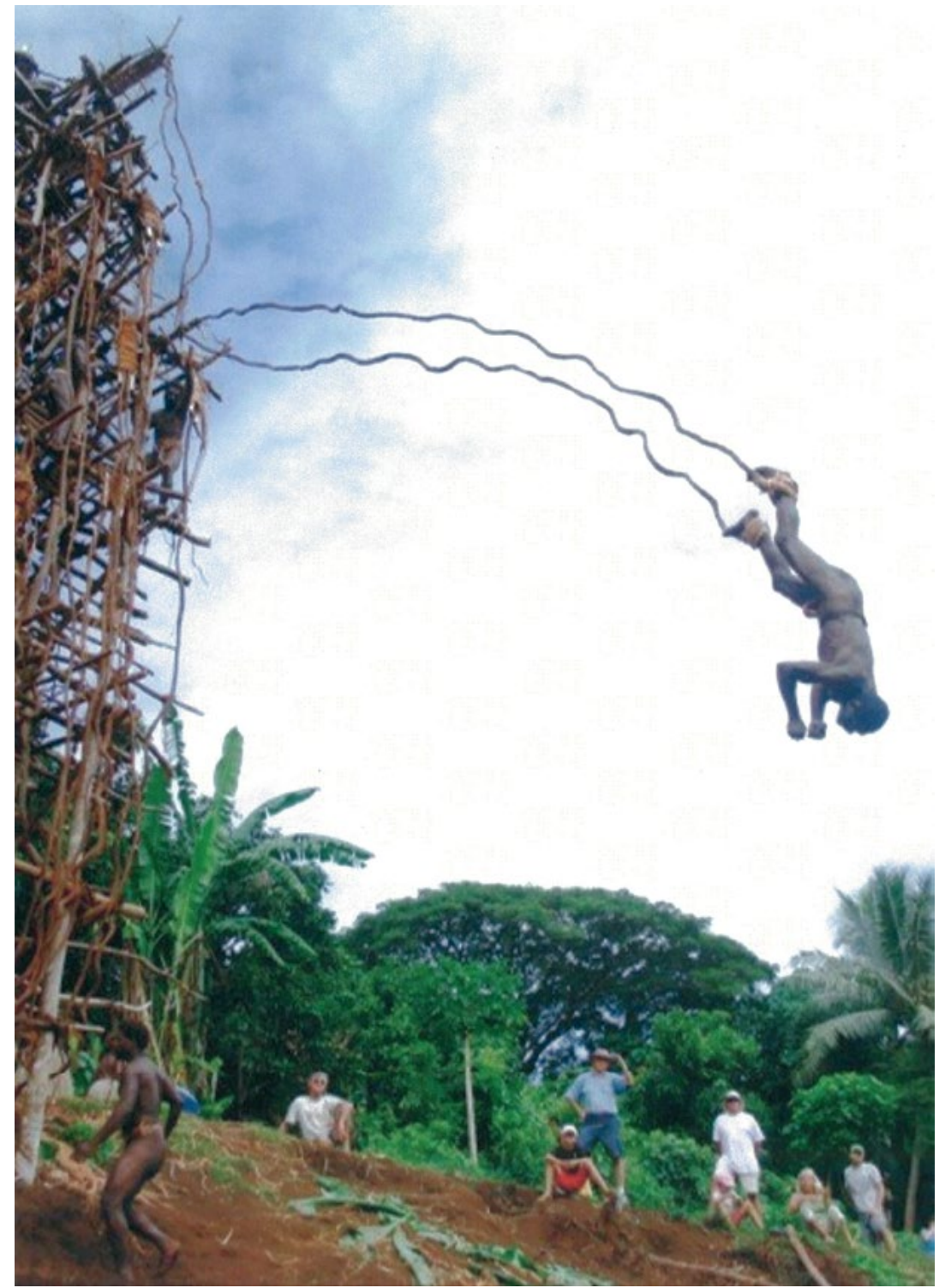

Figure 68. Tourists witnessing a gol on the west coast of Pentecost. Source. Photographed by John Taylor, Pentecost, 9 June 2007. 


\section{A carnival of commodities? Cultural custodianship, intellectual property and emergent male individualism}

The gol is now absolutely entangled with money, as tightly as the vines are lashed onto its logs. For some this entanglement is a sign of a 'carnival of kastom'; 65 of how culture has become reified as kastom and how commoditisation promotes emergent inequalities. There is no doubt that what was likely a ritualised indigenous spectacle in the past has become an aestheticised commodity spectacle performed primarily, if not exclusively, for tourists. But to see this as 'inauthentic', or as cultural degeneration, presumes a view of culture as a timeless, pure whole. ${ }^{66}$ It suggests a romantic view of culture as eternal, beyond the worlding of historical change and ultimately reinscribes a vision of culture as unsullied by time or external influences, in a way uncannily akin to the rhetoric and visual lures of much tourist promotion.

Moreover, in this case the emergent inequalities deriving from the commoditisation of kastom provokes contesting masculinities in newly risky and sometimes deadly ways. And this again is not just local but worlded. This engages ni-Vanuatu men emerging as individualist entrepreneurs aspiring to control their 'intellectual' or 'cultural property' on Pentecost Island in the context of new national and global regimes of heritage and of copyright. It also involves those who are attempting to control and sometimes suppress the business and perceived corruption from Port Vila, or even as far away as Munich. It engages those white men who have become fascinated from a distance, those who have witnessed it as a spectacle in the flesh or on the screen and have imitated the performance either in its indigenous form (like Kal Muller or Karl Pilkington in a hilarious satire as An Idiot Abroad on YouTube, viewed over 75,000 times). Or those who have participated in the extreme global sport of bungee jumping. This congregation includes more distant culture brokers who have facilitated and fuelled its status as an iconic national and global spectacle and those who have criticised and attempted to corral it. My own work, including this text, is surely an integral part of

65 Tabani, 'The carnival of custom'.

66 Margaret Jolly, 1992, 'Specters of inauthenticity', The Contemporary Pacific 4(1): 49-72; Tabani, 'The carnival of custom', p. 310. 
such a process of worlding. But I suggest the gendered nature of the gol itself exerts a dynamic and dangerous allure that remains fundamentally masculine.

So, in conclusion, let me elaborate my arguments in the light of recent appraisals of the gol by Marc Tabani, Miranda Forsyth and John Taylor. I agree with Tabani that there has been an aestheticisation of an 'authentic' kastom at work here and that there are crucial contests since the gol is iconic not just of Pentecost but of Vanuatu and its tourist branding. ${ }^{67}$ As Tabani insists the gol is promoted by diverse governments in Vanuatu as a symbol par excellence of 'traditional knowledge and expressions of culture' (TKEC), as formulated by UNESCO.$^{68}$ This was clear in dealings with Alan Hackett, who although he long acknowledged the inspiration of gol in bungee jumping, insisted that his technical innovations warranted intellectual property patents. ${ }^{69}$ The worth of his business is now estimated at about US $\$ 80$ million. A legal case of breach of intellectual property rights against Alan Hackett, was not just a claim for compensation by people from Pentecost but became a national concern articulated by the Vanuatu Prime Minister and the Attorney General in 1995. These contests both within the archipelago and with overseas entrepreneurs likewise have a markedly masculine character: they are contests between men for control over a supremely masculine spectacle.

I also agree with Forsyth that there are incredible tensions between competing approaches to intellectual and cultural property. ${ }^{70}$ These contests are complex and intense, engaging national, regional and global regulation, especially since the formation of the World Intellectual Property Organization (WIPO) in 1999 as a United Nations instrument and the recognition of both traditional knowledge (TK) and Traditional Cultural Expressions (TEC) as a basis for UN Conventions, regional treaties and charters and national legislation in

\footnotetext{
67 Tabani, 'The carnival of custom'.

68 Ibid., p. 316.

69 Alan Hackett a New Zealander entrepreneur, long interested in extreme sports popularised bungee (or bungy) jumping, first by jumping off bridges in his native country in 1986 and then by a jump from the Eiffel Tower in 1987. He first used a parachute harness but later developed an ankle harness with an extremely elastic cord. He established bungee jumping sites in Queenstown, NZ, and later Australia, France, Germany, Indonesia and the US. His autobiography chronicles his contributions to adventure tourism. See John Alan Hackett, 2006, Jump Start. The Autobiography of Bungy Pioneer A.J. Hackett, Auckland: Random House.

70 Forsyth, 'Lifting the lid on "the community"'.
} 
the Pacific. ${ }^{71}$ Forsyth warns against the assumption that recognising TK perforce means recognising property rights. She argues that reified ideas of kastom and 'community' occlude the political contests and disputes going on within and between peoples in this diverse cultural region. As we have seen, this is palpable in recent contests about the gol within and beyond Pentecost. We have also witnessed how these local contests are articulated with contests involving state and global agencies: 'Indigenous people are not immune from seeking to capitalize on control over traditional knowledge in order to commodify it and profit from it, and state laws and foreign purses can become very effective tools in manipulating claims by one individual against another. ${ }^{72}$

Moreover, the local use of the language of 'property' for the gol is akin to the property claims and use of state legal powers with the commoditisation of indigenous land as real estate by powerful male leaders and jifs, especially on the island of Efate. ${ }^{73}$ It names a novel power asserted by individual male entrepreneurs who claim the authority, often as chiefs to own and control the gol as theirs. Witness the strenuous claims by Jif Telkon Watas to protect not just his financial but his cultural capital invested in the gol as a right derived from his pre-eminent authority as a chief. Even as agents of the state portrayed him as an avaricious even unworthy jif, they had to acknowledge the pervasive legitimacy of chiefs in the post-colonial state and the growing legitimacy of the concepts of intellectual and cultural property, ever since the debate about a national Copyright

71 See Tabani, 'The carnival of custom'; and Forsyth, 'Lifting the lid on "the community"', for details of these. Forsyth, discerns three distinct initiatives apropos the TK of the gol: the sui generis initiative adopted in Vanuatu's Copyright Act formulated in 2000 but not gazetted till 2011; the cultural industries initiative; and that grounded in the ICH Convention, which aims to safeguard intangible cultural heritage for the benefit of all humanity. These diverse approaches have different implications for the locus of ultimate control and the concentration and spread of financial benefits. Forsyth summarises their divergent emphases thus: the sui generis legislation that presumes no defining characteristics is aimed to prevent misappropriation and commercialisation, the cultural industries approach is focused on commercialisation and the ICH convention is predominantly about preservation. She discerns crucial tensions between them in how they deal with political and practical issues in the fraught relation between commerce and culture, and who they empower at local, national and regional levels.

72 Forsyth, 'Lifting the lid on "the community"', p. 3.

73 See McDonnell, 'Exploring the cultural power of land law in Vanuatu: Law as a performance that creates meaning and identities'; McDonnell, 'My land my life: Power, property and identity in land transformations in Vanuatu'. I thank Siobhan McDonnell for crucial insights here. I have had the benefit of reading her published and forthcoming papers as well as chapters from her fine PhD thesis, recently awarded. 
Act from 2000. The debate was rather about who had the power to control and regulate and on what basis. All of the contenders were men, from local and regional jifs to national judges, cultural custodians and politicians.

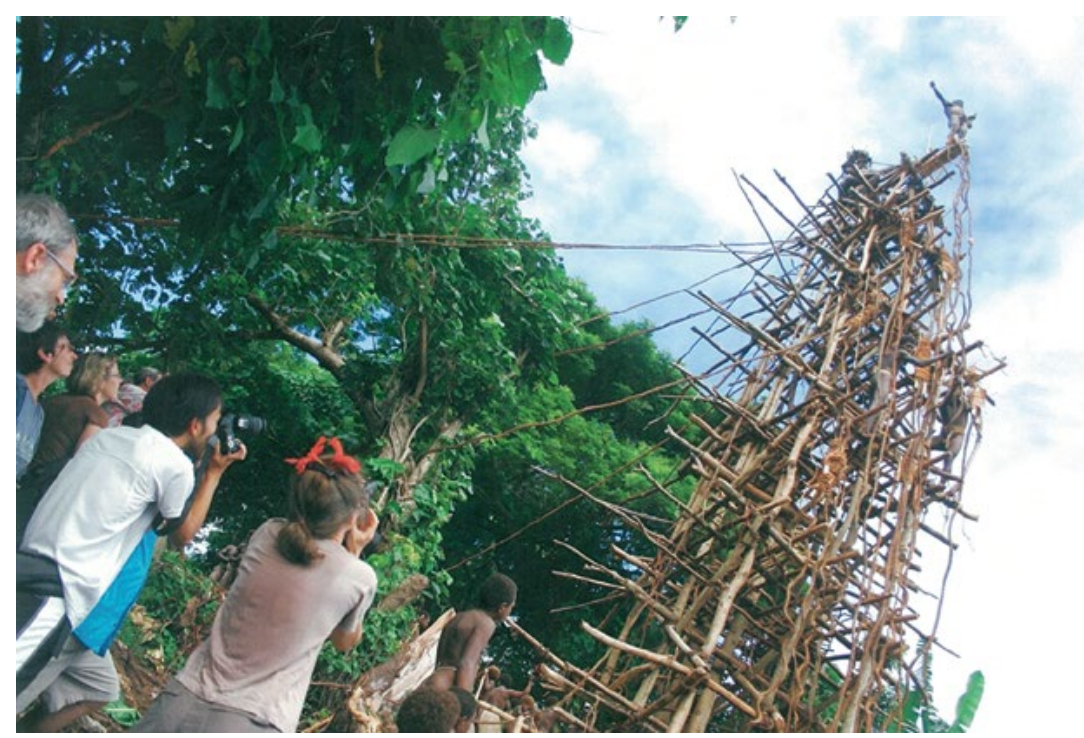

Figure 69. Spectators, necks craning upwards, and feeling 'uncannily disempowered' or 'small' underneath the tower.

Source. Photographed by John Taylor, Pentecost, 9 June 2007.

John Taylor has, in an innovative article, rather looked at the intersubjective character of the performance of gol based on his firsthand experiences between 2000 and 2008. ${ }^{74} \mathrm{He}$ suggests that it is more than just an exotic spectacle or 'staged authenticity', whereby locals and tourists are 'unwilling puppets performing a gaudy dance on the fingertips of some nebulously conceived "'tourism industry"'. ${ }^{75}$ I agree. Such a view is demeaning of both and fails to take into account the extraordinary corporeal energy and emotions experienced by divers and spectators alike, with pulses racing and, from the viewpoint of scopophiliac spectators, necks craning upwards, and feeling 'uncannily disempowered' or 'small' underneath

74 John Taylor, 2010, 'Photogenic authenticity and the spectacular in tourism', La Ricerca Folkorica, special issue Indigenous Tourism and the Intricacies of Cross-cultural Understanding 61: 33-40.

75 Ibid., p. 38. 
the tower (in the words of a fellow male tourist) ${ }^{76} \mathrm{He}$ highlights his sense not just of exotic difference but of human sameness in the shared experience of risk, of fragility, impermanence and ultimate transcendence. He celebrates this sense of connection with rather than of racial and cultural difference from the male divers as he stands being photographed with them after the event they mutually experienced. But, crucially, both the sense of sameness and difference is here again experienced in a canonically masculine mode.

But finally I return to Jif Telkon and to that bitter dispute with Thorolf Lipp about his right to control the gol and its worlding. In the pages of The Contemporary Pacific, Lipp published a dialogue with Guido Pigliasco on their twin projects of 'collaboration' in contemporary Oceania. ${ }^{77}$ Here Lipp reflects on the events of 2009 and how his connection with the Bunlap community was hampered by Jif Telkon's presumptuous, violent authority. Here Lipp portrays Jif Telkon as mythologising and exploiting his chiefly ancestry as a natural right, observing that his promises to use profits for communal development on the island had rarely eventuated. He stresses that Jif Telkon Watas left the island of Pentecost long ago, and 'returns only sporadically to Bunlap'.$^{78}$ There is no doubt that even close kin of Telkon in Bunlap chafed at his continuing chiefly authority over them; on our visit to Bunlap in April 2013 some labelled him 'man Efate'. Yet, as a man making money from kastom, he seemed to attract more opprobrium than his Christian kin, rival custodians of the gol. Engagement with the commodity economy seems to fit more comfortably with being a Christian man, for whom cashcropping and small business have long been a valued way of making a living, and does not seem to compromise their legitimacy as ni-Vanuatu men or as chiefs in a way similar to men of kastom. Moreover, Lipp acknowledges the moral peril of condemning Jif Telkon Watas for 'having attitudes on which our own society is largely built'.$^{79}$

\footnotetext{
76 Ibid., p. 36.

77 Pigliasco and Lipp, 'The islands have memory'.

78 Ibid., p. 393.

79 Ibid., p. 394.
} 
But in the pages of that scholarly journal (which Telkon could not read), Lipp went rather further to discredit his authority:

Telkon clearly was the 'local custodian' of the gol, but his knowledge about it, compared to that of other kastom Sa, was not very elaborate. Nor did learning more about this heritage, its history and its diverse meanings - for the sake of just knowing and potentially preserving it - occur to him as something positive or necessary. ${ }^{80}$

This suggests the moral superiority of those who learn about and preserve kastom as a value in itself (ni-Vanuatu filwokas, foreign anthropologists?) as against those for whom there is a practical even a pecuniary interest. ${ }^{81}$ As far as I know, Telkon was not aware of this published critique but it is intriguing that with failing health and the prospect of his own imminent mortality, he chose to perform and record for posterity his own epic version of the dun na gol.

\section{A small gol at Erakor Haf Rod}

This extraordinary epic was performed at Erakor Haf Rod, and recorded by Murray Garde and the late filmmaker Kim McKenzie, on 28 September 2012. Murray and Kim arrived to find Telkon and his son, Warisus, dressed in their best penis sheaths and bark belts with pigs' tusks glistening on their breasts, palpable signs of their high rank. They had erected a small replica of the gol about three metres high, not unlike that which was erected outside the museum in Munich. This tower was meticulous in its use of materials, its geometry, and in the details of its platforms and struts. As he spoke, Telkon clutched a yam to stress the intimate imbrication of growing yams and making towers, visibly moving those who jumped and those who watched with the thrill of a masculine spectacle. He then proceeded to tell a very long story, which artfully linked other dun na ngamômô to the gol. The transcript of those words in Sa, and English translation runs to 48 pages. ${ }^{82}$ It was not only a long but a very elaborate epic.

80 Ibid., p. 393.

81 Ibid., p. 394. This seems to neglect the material and personal career benefits of doing anthropology and making films.

82 Watas and Garde, Dun na gol. 


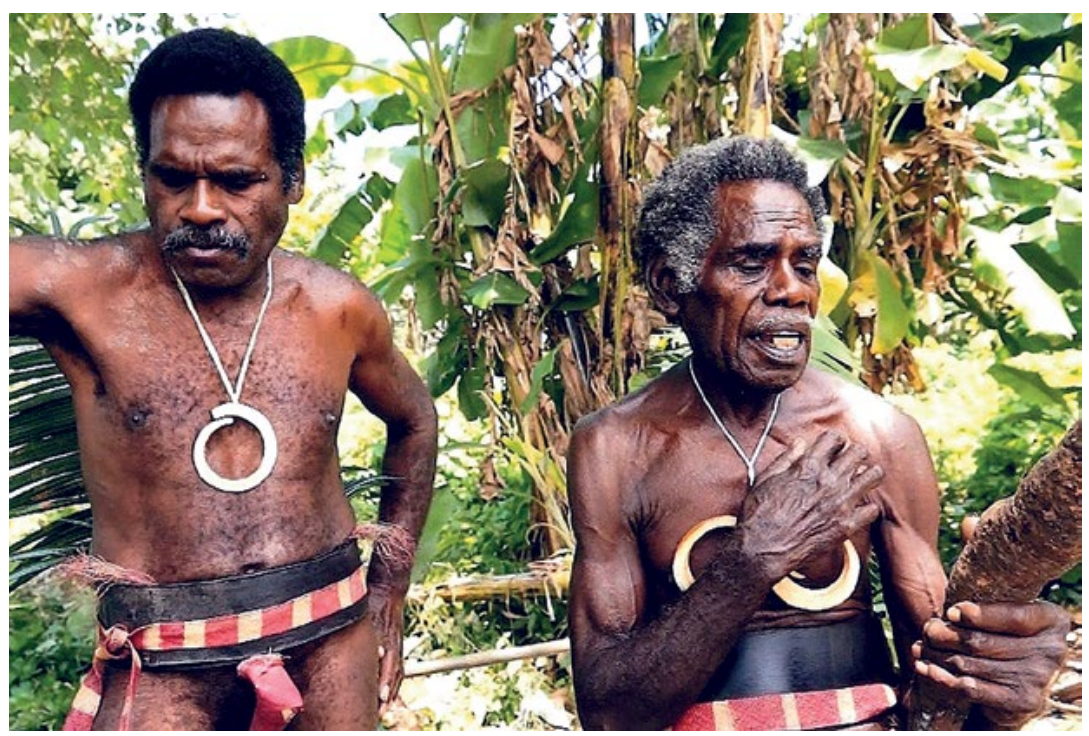

Figure 70. Jif Telkon Watas clutching a yam and his son Waris Sus.

Source. Still from film of Kim McKenzie, 28 September 2012, courtesy of Murray Garde.

Following Garde's consummate analysis we can distil some of the crucial features of this telling. ${ }^{83}$ Telkon linked the site of the original tower to Rebrion, the place where the first human beings (all men) emerged and where one was converted to a woman, Sermop, through the agency of hot chestnuts. ${ }^{84} \mathrm{He}$ tied this story to that of Singit, a man whose body was the origin of yams of all kinds. The sacred site of Rebrion is one over which his buluim (place-based descent group) claims custodianship and control. ${ }^{85}$ Telling the story or the history of the origin in this way was also a claim to precedence or even originary ownership, not just of that place but the practice of the gol. Telkon concluded his epic with the words: 'nê ae nê bos natê, nê mbe bos na gol Vanuatu' (I, I am the boss of it; I am the boss of the gol of Vanuatu).

In other contexts where different versions of the dun na gol have been told there has been much discussion over which one is 'true'. At a community meeting of the Wawan Association of South Pentecost in 2011 where five versions of dun na gol were told, the version told by

83 Garde, "Stories of long ago" and the forces of modernity in South Pentecost'.

84 See Jolly, Women of the Place, pp. 141-43; Jolly, 'Spouses and siblings in Sa stories'.

85 Garde also notes a link between this claim to origin and that of Luke Fargo of Londot, but since this is restricted knowledge that cannot be detailed here. 
Jif Telkon was seemingly supported by most of the 26 communities represented. ${ }^{86}$ The idea of 'truth' or authenticity here seems to combine both the idea of a spatio-temporal origin and of a compelling telling. But, as Garde shows, the conversion of oral narratives into texts also imparts an air of 'authenticity' detached from the original contexts. Telkon's version, which was over 4,000 words, had been typed up and circulated at that meeting in 2011. And in the version filmed by Garde and Mackenzie in September 2012, Telkon frequently cited that written text of his own prior telling, to give more details that he did not choose to repeat and were thereby imbued with undisputed authority. As Garde astutely observes for Telkon's narrative, the Sa word for 'we' changes: the exclusive form gema is used when he references close kin and the truth of the story is seen as contestable; the all inclusive form kêt is used to refer to 'all of us' when an uncontestable truth is articulated. ${ }^{87}$

In my own experience and that of Murray Garde, Sa-speaking people young and old, have been keen to get copies of Elie Tattevin's texts published in the early twentieth century $(1915,1929,1931)$ as seemingly dispassionate, disembodied evidence that might be valued not just as heritage or cultural capital but rhetorical weapons in disputes ${ }^{88}$ After I recorded contemporary versions of dun na ngamômô during my doctoral research, I circulated copies of Tattevin's texts locally. More recently we gave copies of these texts to Bong Désiré, a talented Francophone interlocutor from Baie Barrier who has worked closely with Murray Garde over many years. The other main genre of stories, dun na buluim, are far more restricted in their telling and circulation and are crucial in contests over custodianship and use of land till today. The varieties of telling of origin stories of long ago, such as the origin of life or sexual difference are not nearly so consequential although they may serve individual strategic interests. ${ }^{89}$ But contests about how to best tell the story of the land dive are now we see

86 Garde, "'Stories of long ago" and the forces of modernity in South Pentecost', p. 11.

87 I discerned a similar pattern in recordings of dispute meetings in Sa in the 1970s as litigants moved from expressing disputes based on contestable grounds (gema, an exclusive 'we') to expressing an all inclusive consensus ( $k e \hat{t}$, the inclusive 'we') emerging with a successful conclusion to a meeting.

88 Élie Tattevin, 1915, 'A l'ombre des ignames. Mythes et légendes de l'île Pentecôte', Les Missionnes Catholiques 47: 213, 226-27, 236-37; Tattevin, 'Mythes et Légendes du Sud de I'île Pentecôte'; Tattevin, 'Mythes et Légendes du Sud de I'île Pentecôte'.

89 See Jolly, 'Spouses and siblings in Sa stories'. 
potentially a deadly combat. This combat is not just between local men as individualist entrepreneurs but articulates these contests with broader national and global relations.

His performance of a novel epic of the gol was a claim to pre-eminent custodianship and control by Jif Telkon Watas. He says as much. In the 18 months after this film was made his health deteriorated rapidly and, since neither the medicine of kastom nor the hospital in Port Vila had delivered a cure or indeed much relief, we heard late in 2013 that he had gone home to Pentecost, to Bunlap, close to Rebrion, where his life and indeed all life began. He died there on 8 January 2014. The world he had imagined and fashioned through the travels of gol thus returned home too.

\section{Acknowledgements}

My heartfelt thanks to the people of South Pentecost for welcoming me with such hospitality, familarity, and good humour, first as a young woman in the 1970s and more recently as an old woman or jiwit. Particular thanks to the late Jif Telkon Watas for his epic recording of the dun na gol with Murray Garde and the late Kim McKenzie. Murray has been an exceptional colleague and I thank him greatly for his rigour, empathy, generosity and wit on our travels together between Canberra, Vila and Pentecost. A huge thanks to Sabine Hess for the excellent distillation and translation of Lipp's German text. Thanks are also due to several colleagues for close readings and suggestions on this essay in various iterations, including Chris Ballard, Miranda Forsyth, Murray Garde, Siobhan McDonnell, Greg Rawlings, Lamont (Monty) Lindstrom and John (Jack) Taylor, my editor. Thanks to Murray, Monty and Jack for permission to use their photographs in this volume and to the copyright holders of other images. I also benefited greatly from discussions of this paper in the Reading and Writing Group of our Laureate Project, and when I presented it at the Australian Anthropological Society meetings in Canberra, 6-8 November 2013, in The Australian National University Anthropology series on 5 March 2014, and in a much shorter version at the European Society for Oceanists in Brussels in July 2015. All errors and infelicities remaining are mine. This research was generously funded by The Australian National University and the Australian 
Research Council Laureate Fellowship 'Engendering Persons, Transforming Things: Christianities, Commodities and Individualism in Oceania' (FL100100196).

\section{References}

'An Lianen in die Tiefe.' 2009. Süddeutsche Zeitung, June. Online: www. sueddeutsche.de/muenchen/voelkerkundemuseum-muenchen-anlianen-in-die-tiefe-1.97914 (accessed 4 March 2016).

Anthonioz, Pierre. 1953. 'La danse du Gaul dans le sud de l'île de Pentecôte.' Mission des isles 46: 6-7.

_. 1954. 'La danse du Gaul, céremonie rituelle de l'île Pentecôte.' Etudes Mélanésiennes 8: 92-95.

Connell, R.W. and James W. Messerschmidt. 2005. 'Hegemonic masculinity: Rethinking the concept.' Gender and Society 19(6): 829-59.

Forsyth, Miranda. 2012. 'Lifting the lid on "the community": Who has the right to control access to traditional knowledge and cultural expression.' International Journal of Cultural Property 19: 1-31.

Garde, Murray. 2015. "Stories of long ago" and the forces of modernity in South Pentecost.' In Narrative Practices and Identity Constructions in the Pacific Islands, ed. Farzana Gounder, pp. 133-52. Amsterdam: John Benjamins, Studies in Narrative series.

Hackett, Alan John. 2006. Jump Start. The Autobiography of Bungy Pioneer A.J. Hackett. Auckland: Random House.

Jolly, Margaret. 1981. 'People and their products in South Pentecost.' In Vanuatu: Politics, Economics and Ritual in Island Melanesia, ed. Michael Allen, pp. 269-93. Sydney and New York: Academic Press.

- 1991. 'Gifts, commodities and corporeality: Food and gender in South Pentecost.' Canberra Anthropology 14(1): 45-66.

- 1992. 'Specters of inauthenticity.' The Contemporary Pacific 4(1): $49-72$. 
- 1994. Women of the Place: Kastom, Colonialism, and Gender in Vanuatu. Philadelphia: Harwood Academic Publishers.

- 1994. 'Kastom as commodity: The land dive as indigenous rite and tourist spectacle in Vanuatu.' In Culture - Kastom - Tradition. Developing Cultural Policy in Melanesia, ed. Lamont Lindstrom and Geoffrey White, pp. 131-44. Suva: Institute of Pacific Studies, University of the South Pacific.

—. 1999. 'Another time, another place.' Oceania 69(4):282-99.

- 2001. 'Damming the rivers of milk? Fertility, sexuality, and modernity in Melanesia and Amazonia.' In Gender in Amazonia and Melanesia: An Exploration of the Comparative Method, ed. Thomas A. Gregor and Donald Tuzin, pp. 175-206. Berkeley: University of California Press.

—. 2003. 'Spouses and siblings in Sa stories.' The Australian Journal of Anthropology 14(2): 188-208.

- 2008. 'Introduction. Moving masculinities: Memories and bodies across Oceania in Re-membering Oceanic Masculinities.' The Contemporary Pacific 20(1): 1-24.

- 2014. 'A saturated history of Christianity and cloth.' In Divine Domesticities: Christian Paradoxes in Asia and the Pacific, ed. Hyaeweol Choi and Margaret Jolly, pp. 429-54. Canberra: ANU Press. Online: press.anu.edu.au/publications/divine-domesticities (accessed 4 March 2016).

- 2016. 'Men of war, men of peace: Changing masculinities in Vanuatu.' In Emerging Masculinities in the Pacific, ed. Aletta Biersack and Martha Macintyre. The Asia Pacific Journal of Anthropology, 17(3-4): 306-323.

Johnson, Irving and Electra Johnson. 1955. 'South Seas incredible land divers.' National Geographic January: 77-92.

Kleinert, Martina and Thorolf Lipp (eds). 2015. Auf Augenhöhe? Von Begegnungen mit der Südsee und angewandter Ethnologie. Berlin: Reimer. 
Lipp, Thorolf. 2008. Gol. Turmpsingen auf der Insel Pentecost in Vanuatu. Beschreibung und Analyse eines riskanten Spektakels (Gol: Land Diving on the Island of Pentecost in Vanuatu: A Description and Analysis of a Risky Spectacle). Berlin: Lit Verlag.

—. 2009. UrSprung in der Südsee: Begugnung mit den Turmspringurm von Pentecost. Online: www.ursprung-in-der-suedsee.de (accessed 24 February 2015).

- n.d. Immaterielle Kulture im Museum. Die Turmspringen von Pentecost besuchen Indstrom Deutschland. Berlin: Reimer.

McDonnell, Siobhan. 2013. 'Exploring the cultural power of land law in Vanuatu: Law as a performance that creates meaning and identities.' In Grounding Travelling Concepts: Dialogues with Sally Engle Merry about Gender and Justice, ed. Hilary Charlesworth and Margaret Jolly. Intersections: Gender and Sexuality in Asia and the Pacific, issue 33. Online: intersections.anu.edu.au/issue33/forsyth. htm (accessed 4 March 2016).

—. 2016. 'My land my life: Power, property and identity in land transformations in Vanuatu.' PhD thesis. The Australian National University.

Monnier, Paul. 1991. L'eglise catholique au Vanuatu. Port Vila: Mission Mariste.

Muller, Kal. 1970. 'Land diving with the Pentecost Islanders.' National Geographic 1138(6): 796-817.

—. 1971. 'Le Saut du Gaul dans le sud de l'île de la Pentecôte, Nouvelles-Hébrides.' Journal de la Société-des Océanistes 32: 219-234.

Pigliasco, Guido Carlo and Thorolf Lipp. 2011. 'The islands have memory: Reflections on two collaborative projects in contemporary Oceania.' The Contemporary Pacific 23(2): 371-410.

Rumsey, Alan and Don Niles (eds). 2011. Sung Tales from the Papua New Guinea Highlands: Studies in Form, Meaning, and Sociocultural Context. Canberra: ANU E Press. Online: press.anu. edu.au/publications/sung-tales-papua-new-guinea-highlands (accessed 23 April 2016). 
Siméoni, Patricia. 2009. Atlas du Vanouatou (Vanuatu). Port Vila: Éditions Géo-consulte.

Tabani, Marc. 2008. Une pirogue pour le paradis. Le culte de John Frum à Tanna (Vanuatu). Paris: Editions de la Maison des Sciences de l'Homme.

- 2010. 'The carnival of custom: Land dives, millenarian parades and other spectacular ritualizations in Vanuatu.' Oceania 80(3): 309-28.

Tattevin, Élie. 1915. 'A l'ombre des ignames. Mythes et légendes de l'île Pentecôte.' Les Missionnes Catholiques 47: 213, 226-27, 236-37.

_ 1927. 'Sur les bords de la mer sauvage.' Revue d'Histoire des Missions 4: 82-97, 407-429, 557-59.

_ 1929. 'Mythes et Légendes du Sud de I'île Pentecôte.' Anthropos 24: 983-1004.

_ 1931. 'Mythes et Légendes du Sud de I'île Pentecôte.' Anthropos 26: $489-512,863-81$.

Taylor, John. 2010. 'Photogenic authenticity and the spectacular in tourism.' La Ricerca Folkorica. Special issue Indigenous Tourism and the Intricacies of Cross-cultural Understanding 61: 33-40.

Vanuatu Cultural Centre website. n.d. Online: www.vanuatuculture.org (accessed 4 May 2006, link subsequently removed).

Watas, Telkon and Murray Garde. 2012. Dun na gol, transcribed and translated by Murray Garde, filmed by Kim McKenzie, September.

\section{Visual and online sources}

Gray, M. OMalley. 2010. Tribal Life Bunlap. 2010. Online: www. youtube.com/watch?v=F7rUrCBQzY4 (accessed 4 March 2016).

Merchant, Stephen, Karl Pilkington, Ricky Gervais. 2010. An Idiot Abroad: Karl Pilkington. British Sky Broadcasting. 
Muller, Kal. 1972. Land Divers of Melanesia (with Robert Gardner for Film Study Centre, Harvard University). Distributed by Documentary Educational Resources. Online: www.der.org/films/ landdivers-of-melanesia.html (accessed 4 March 2016).

Primal Vision Productions. 2006. Meet the Bunlaps. Televison series released in United States. Described as 'funky six part series on people who prefer penis sheaths to clothes and pigs to money'. Online: primalvision.com.au (accessed 4 March 2016).

Seale, John (director). 1990. Till there was you. Written by Michael Thomas. 
This text is taken from Touring Pacific Cultures, edited by Kalissa Alexeyeff and John Taylor, published 2016 by ANU Press, The Australian National University, Canberra, Australia. 